\title{
O DISCURSO DO CONSUMO MORALISTA, NA REVISTA TURMA DA MÔNICA JOVEM
}

\author{
THE SPEECH OF THE MORALIST CONSUMPTION IN THE MAGAZINE TURMA DA MÔNICA JOVEM
}

\author{
Flávia Meneguelli Ribeiro Setubal \\ Professora Adjunto I DE, área de Marketing - Universidade Federal do Espírito Santo - Departamento de \\ Administração. \\ Vila Velha, ES, Brasil \\ E-mail: flaviamenega@terra.com.br
}

\section{Moema Martins Rebouças}

Professor Associado III DE, área de Educação e Linguagens - Universidade Federal do Espírito Santo Programa de Pós-graduação em Educação.

Vitória, ES, Brasil

E-mail: moemareboucas@gmail.com

\section{RESUMO}

A proposta do artigo é contribuir no âmbito educacional e dos estudos do consumo, desenvolvendo uma análise crítica da revista em quadrinhos Turma da Mônica Jovem (TMJ), dentro dos pressupostos teóricos e metodológicos dos estudos da semiótica discursiva, tendo como pano de fundo a sociedade de consumo atual. $O$ corpus é formado pela edição 58 , intitulada "Conflito de Gerações", com o objetivo de identificar como o discurso do consumo moralista é apropriado pela revista, bem como que estratégias enunciativas são utilizadas para inscrever o público infantojuvenil neste discurso. Os resultados apontam para um alerta ao consumo desordenado de informações na internet, reiterando uma característica marcante do público infantojuvenil de TMJ, uma vez que seu discurso figurativiza essa relação jovens $x$ tecnologia, o tempo todo. Ainda, a categoria de consumo moralista tem foco no público masculino, colocando os meninos como personagens principais das tramas ou situações apresentadas.

Palavras-chave: Consumo Infantil. Consumo Moralista. Semiótica. Educação. Turma da Mônica Jovem.

Data de submissão: 15 de maio de 2015.

\section{ABSTRACT}

The purpose of this paper is to contribute in the field of education and consumption studies, developing a critical analysis of Monica Young (TMJ) comic book, within the theoretical and methodological assumptions of the discursive semiotic studies, in the contemporary consumption society. The corpus is formed by the edition number 58 entitled "Conflicts of Generations", with the aim of identifying how the discourse of moral consumption is appropriated by the comic book, and also what enunciation strategies are used to include the youth public into its discourse. The results show an alert to the disorderly use of information on the Internet, reiterating a hallmark of youth TMJ public, since its discourse figurativize this young $x$ technology relationship, all the time. Yet, the moralist consumption category focuses on the male audience, putting the boys as the main characters of the presented plots or situations

Keywords: Child Consumption. Moralist Consumption. Semiotics, Education. Monica Young.

Data de aprovação: 27 de julho de 2016. 


\section{INTRODUÇÃO}

Eles cresceram! Como aconteceu com seus leitores que, desde o ano de sua criação, em 1963, acompanham as aventuras da famosa turma. Hoje, Mônica, Cebolinha, Cascão, Magali e outros personagens são adolescentes que namoram, se preocupam com sua aparência, com seu futuro, dentre outros questionamentos típicos da fase que atravessam.

Criada em agosto de 2008, a revista em quadrinhos "Turma da Mônica Jovem" tem estilo mangá (referência aos quadrinhos japoneses) e traz os mesmos personagens, mas com características bem distintas da antiga turma: Mônica não é mais baixinha e gorducha; Magali come moderadamente e tem uma alimentação saudável; Cebolinha foi à fonoaudióloga e só fala errado quando está nervoso e, por fim, o Cascão toma banho, periodicamente.

Tradicionalmente, as histórias da "Turma da Mônica" possuem um viés instrutivo-educativo, no sentido de valorizar comportamentos e atitudes por parte das crianças leitoras.

Em pesquisa detalhada sobre a obra quadrinizada de Maurício de Sousa, Santana (2007) percebeu a presença de discursos com preocupação pedagógica, ecológica e religiosa que, segundo o autor, são, de certo modo, direcionados para a prática educativa e a transmissão de valores morais e éticos considerados positivos, em nossa sociedade.

Esta transmissão de valores ocorre através dos seus personagens, os quais mostram o caminho a ser seguido, as escolhas a serem feitas para que se possa desenvolver uma boa personalidade, adquirindo-se também uma formação moral correta, sem vícios e desvios de conduta, tudo isto de acordo com o ponto de vista do locutor que representa a posição de um dado sujeito discursivo (SANTANA, 2007, p. 88).

Entretanto, nas histórias de TMJ, essa transmissão de ensinamentos não é tão clara como nas histórias originais, abrindo margem para diversas apreensões do enunciado pelo público leitor da revista.

Como estudiosa dos processos de consumo, o interesse nessa pesquisa surgiu, a partir da leitura da TMJ no 19 - intitulada "Surge uma estrela". Na edição, Magali se via às voltas com o mundo do sucesso, ao ser selecionada para compor o casting da banda Star Stars, derrotando sua melhor amiga, Mônica. Na história, Magali enfrenta o dilema entre ter "glamour e fãs, brilho e magia, o sonho de toda garota" (SOUSA, 2010, p. 5-6) e a amizade de Mônica, ressentida com a mudança de comportamento de Magali. A partir daí, o desenrolar da trama apresenta o que seria o mundo ideal de uma estrela: namorados famosos, descolados, boa pinta, produzidos; alface e tomate no almoço, para melhorar a performance e a silhueta; problemas na escola decorrentes do sono, durante as aulas; dentre outras pistas que representam a sociedade de consumo contemporânea.

Essa denominação, utilizada por estudiosos da área, se justifica a partir do momento em que se identifica que a cultura material e o consumo são aspectos fundamentais de qualquer sociedade, porém somente a sociedade moderna contemporânea tem sido caracterizada como uma sociedade de consumo. Isso porque o consumo está preenchendo, para os indivíduos desta, uma função acima e além daquela de satisfação das necessidades materiais e de reprodução social comum aos demais grupos sociais (BARBOSA, 2004). 
O consumo possui uma óbvia presença, tanto ideológica quanto prática, no mundo em que vivemos, pois é um fato social que atravessa a cena contemporânea de forma inapelável. Ele é algo central na vida cotidiana, ocupando, constantemente (mais mesmo do que gostaríamos), nosso imaginário. O consumo assume lugar primordial como estruturador dos valores e práticas que regulam relações sociais, que constroem identidades e definem mapas culturais. Também, como é próprio de fenômenos deste porte, demanda, insistentemente, reflexões, interpretações e teorias (ROCHA, 2005, p. 124).

O artigo aqui proposto traz uma análise que faz parte da tese intitulada "Educação em consumo, na linguagem dos quadrinhos: uma análise crítica da revista Turma da Mônica Jovem", desenvolvida dentro dos pressupostos teóricos e metodológicos dos estudos da semiótica discursiva, tendo como pano de fundo a sociedade de consumo atual. Na tese em questão, cinco categorias de consumo foram analisadas: o consumo conspícuo, o consumo consciente, o consumo de cultura midiática e o consumo moralista, cujo recorte é objeto de análise deste artigo.

A relevância de uma análise semiótica das histórias em quadrinhos contemporâneas, nesse caso específico, da "Turma da Mônica Jovem", se dá pela relação da HQ, compreendida no gênero da literatura infantojuvenil, com o campo da educação, uma vez que a mesma pode ser entendida como mecanismo de disseminação de valores, condutas e comportamentos próprios da sociedade vigente.

Hoje, mais que nunca na história, os agentes privilegiados no processo de (re)criação e difusão de valores, comportamentos, gostos, idéias, personagens virtuais e ficção são as grandes empresas transnacionais da mídia, da publicidade e do entretenimento" (MOREIRA, 2003, p. 1207).

Essas corporações, que reúnem televisão, vídeo, cinema, computadores, Internet, aparelhos de diversão eletrônicos e, ainda, rádios, revistas, jornais, outdoors, banners e diversas formas de comunicação imagética, sonora e/ou virtual, são agentes sociais poderosos. Segundo Moreira (2003), o sistema midiáticocultural, agentes da educação informal aqui tratados, elabora e difunde, de forma não totalmente intencional ou planejada, visões de mundo, sentidos e explicações para a vida e a prática das pessoas e, deste modo, passa a influenciar sempre mais seu cotidiano, sua linguagem e suas crenças. Apesar de o autor considerar essas visões de mundo parcialmente intencionais e planejadas, sabemos que, por trás da indústria midiática, existe todo um arcabouço de pesquisas e estudos na produção e difusão de conhecimento, muito mais intencionais e parciais.

Oswald e Pereira (2008) afirmam que as produções culturais são grandes espelhos usados pela sociedade para se olharem, se repensarem e se recriarem. Por meio delas, as pessoas compartilham descobertas, lutas, indagações e relações de poder, o que pode nos ajudar a pensar a relação do público leitor com a história em quadrinhos.

Assim, desenhos que trazem a criança como protagonista não mais possuem, como habitantes, duendes, bruxas ou fadas, mas, sim, heróis, na pele de crianças, cujas marcas são a autonomia, a competência, o saber e a busca de reconhecimento por mérito próprio, e não por poderes sobrenaturais. Essas, são demandas "atravessadas pelo discurso da criança sábia, autônoma, competente e empreendedora, que prontamente se torna independente dos adultos e apresenta desenvoltura ao lidar com o ambiente tecnológico que a cerca" (SALGADO, 2008, p. 89). 
Dentro do contexto apresentado, o objetivo do presente artigo é analisar como o discurso do consumo moralista é apropriado pela revista Turma da Mônica Jovem, bem como que estratégias enunciativas são utilizadas para inscrever o público infanto-juvenil em seu discurso.

\section{CONCEITOS NORTEADORES DA PESQUISA}

\section{Sociedade de Consumo e Consumo Infantil}

Caracteriza-se como "Sociedade de Consumo" a sociedade em que o consumo desempenha papel central nas inter-relações de seus membros. Nessa sociedade, ele é o modo dominante, porém não o único, de reprodução social e está relacionado a valores, práticas e instituições, tais como escolhas e relações de mercado (BARBOSA, 2004).

Canclini (1999) descreve o consumo como o conjunto de processos socioculturais nos quais se realizam a apropriação e os usos dos produtos. Já para Zukin e Maguire (2004) o consumo é um processo social, cultural e econômico de escolha dos bens. Trata-se de um campo institucional, um conjunto de instituições econômicas e culturais interconectadas, centradas na produção de commodities, destinadas a demandas individuais.

Diante de tantas possibilidades, o consumo tornou-se um campo de investigação complexo, que engloba várias atividades, atores e um conjunto de bens e serviços que não se restringem necessariamente aos providos sob forma de mercadorias, embora a maioria dos autores tenha propensão para enfocar em suas análises bens adquiridos no mercado (BARBOSA; CAMPBELL, 2006).

Nesse contexto atual da sociedade de consumo, vários grupos de consumidores se formam, fazendo com que suas escolhas tenham um sentido simbólico próprio, compreendido e compartilhado por seus seguidores. Um grupo de consumidores que, nas últimas décadas, vem despertando o interesse dos mais variados tipos de empresas, é o consumidor infantojuvenil. As crianças e adolescentes estão desempenhando um papel na sociedade de consumo que muito interessa à indústria, ávida por conquistar e fidelizar esses clientes, desde cedo.

Apesar de - Consumo Infantil - ser o termo técnico utilizado por estudiosos desse campo de pesquisa (o consumo), gostaríamos de esclarecer que o público da revista em quadrinhos "Turma da Mônica Jovem", objeto de estudo em questão, é formado por crianças e adolescentes, segundo definição aceita pelo Estatuto da Criança e do Adolescente, no Brasil. Neste, a Lei 8.069, de 1990, considera criança a pessoa de até 12 anos de idade incompletos e define a adolescência como a faixa etária de 12 a 18 anos de idade (artigo $2^{\circ}$ ). Embora TMJ seja indicada para maiores de 10 anos, ficou constatado, por meio da pesquisa pré-teste realizada e por outros dados informais (conversa com pais, pesquisa em bancas), que os leitores da revista possuem entre nove e dezesseis anos, em média. A maioria deles está, exatamente, no período de transição entre essas duas fases de desenvolvimento. Assim, usaremos o termo Consumo Infantil, por convenção acadêmica, para tratar desse público infantojuvenil descrito.

Segundo McNeal (2007), alguns elementos que fomentam o poder das crianças e adolescentes como consumidores são: a entrada da mulher no mercado de trabalho e consequente aumento da renda familiar; diminuição do índice de fertilidade, havendo mais dinheiro para gastar com os filhos; o retardamento na 
decisão de ter filhos para quando a situação financeira da família já está mais estabelecida; lares separados e aumento de enteados, que acabam recebendo dinheiro de ambas as famílias; famílias de mães ou pais solteiros, em que os filhos passam a participar, mais cedo, do processo de consumo, para ajudar em casa; a importância dos avós na criação e provimento das necessidades financeiras dos netos; o crescimento do fator culpa, devido à falta de tempo dos pais; preocupação dos pais em relação ao futuro das crianças, uma vez que não podem mais contar somente com o Governo para prover necessidades elementares dos filhos.

É costume da geração atual receber dinheiro como presente em datas especiais (Dia das Crianças, aniversário, Natal), sendo que esse item é o segundo preferido no ranking da pesquisa Kids Experts Cartoon Network (ALANA, acesso em 29 abril 2014). Em primeiro lugar, na lista, estão os gadgets eletrônicos como MP3, MP4, iPod e videogames. A pesquisa, realizada em 2006, provavelmente traria, se feita atualmente (2015), os produtos smartphones e tablets como primeiro ou segundo lugar da lista dessas crianças.

O desenvolvimento tecnológico, típico da sociedade contemporânea, vem provocando transformações, no mercado de consumo de mídia e, uma das repercussões mais significativas é a possibilidade de as crianças acessarem, mais facilmente, a internet. Nesse contexto, o consumo de tablets e smartphones desempenham o papel de auxiliar essas crianças a demonstrarem suas habilidades, explorar identidades e sociabilizar com maior amplitude. "De forma lenta, porém contínua, esses aparelhos estão substituindo a televisão como "babá eletrônica". É cada vez mais comum encontrar crianças circulando pela cidade com um tablet' (VELOSO; HILDEBRAND; CAMPOMAR, 2012, p. 15).

Para Young (2004), o entendimento próprio das crianças em relação ao outro, sua psicologia leiga, se estende ao que eles vestem ou consomem. Assim, nos meados da infância, as crianças reconhecem que tipo de garoto ou garota veste determinada marca de calça jeans ou anda em uma bicicleta específica. Eles compreendem o simbolismo do consumo e isso se torna parte integral de suas identidades individuais e grupais. Segundo o autor, as crianças são sensíveis a mudanças de identidades, à medida que crescem e que veem a adolescência retratada, principalmente pela mídia da cultura ocidental, como uma época de prazeres e atrativos. Essas crianças, frequentemente, aspiram serem mais velhas e gostam de desempenhar papéis que propiciem a satisfação desse sentimento. Esse desejo pode ser percebido entre os leitores de TMJ, muitas vezes, crianças que ainda não chegaram na adolescência, mas que aspiram ser como os personagens figurativizados nas revistas, inclusive, aspirando viver suas vidas. Então, se o marketing, a promoção e a propaganda desses bens e serviços de marca são parte dessa cultura, assim, os adolescentes desejam um pedaço dessa ação.

Sobre a adolescência, Rocha e Pereira (2009) afirmam que os jovens passam por um processo constante de mediações entre valores, gostos, hábitos, estéticas, práticas sociais e atitudes, que acontecem, inclusive, entre modos de consumo, uso e valorização de novas tecnologias, adoção de costumes entre a infância e a idade adulta, entre a família e o mundo externo.

Neste período, estamos muitos mais expostos e disponíveis para aprender a consumir, nossos cinco sentidos naturais atentos captam uma avalanche de informações, e outros tantos sentidos artificiais, extensões de nosso corpo, materializados em gadgets tecnológicos, trazem experiências únicas e, ao mesmo tempo, compartilhadas (ROCHA; PEREIRA, 2009, p. 11). 
Dentro deste contexto, a mídia, na forma de propagandas, filmes, desenhos, $\mathrm{HQ}$, etc, enaltece o papel dos jovens e adolescentes, na sociedade vigente, como um forte mediador de inovações tecnológicas e modos de consumo, dentro do núcleo familiar; um papel fundamental, em um mundo repleto de tablets, celulares, computador, entre outros gadgets encontrados, no mercado.

O consumo de produtos (no sentido geral do termo, ou seja, produtos como bens, serviços, ideias, lugares, etc.), está intimamente relacionado à questão da identidade do sujeito. Entre os adolescentes, as possibilidades que esses símbolos de consumo carregam são ainda mais pertinentes. Isso porque eles vivem uma fase de questionamentos, incertezas e descobertas que favorece $o$ ato de atribuir aos produtos meios de afirmar suas identidades, buscando diferenciação social. Assim, dentre as identidades construídas por adolescentes, nessa fase da vida, uma delas é a de consumidor. Isso porque, na sociedade contemporânea, a sociedade de consumo tratada nesta pesquisa, "ser" e "ter" são conceitos intimamente relacionados para os sujeitos da mesma.

Muitas das experiências vivenciadas, na adolescência, estabelecem padrões de comportamento que são mantidos por toda a vida do sujeito, incluindo, assim, os comportamentos de consumo. Nesse sentido, Rocha e Pereira (2009) afirmam que, ao contrário do que pensou Bourdie, em algumas esferas da sociedade, a adolescência parece estar dentro e, mais ainda, no controle do jogo, visto a importância que diversos mercados, como o da moda, o do entretenimento e o da tecnologia, conferem a esse público, objeto de estudos, investimentos e esforços diversos para sua compreensão.

\section{Consumo Moralista}

A visão moralista do consumo é uma das mais antigas, presente em nossa sociedade. Ela considera o consumo como um vilão, ou seja, ele é responsável por diversas mazelas dos tempos atuais. "A simples observação dos discursos cotidianos nos mostra que é muito comum o consumo ser eleito como responsável por uma infinidade de coisas, geralmente associadas aos assim chamados problemas sociais" (ROCHA, 2005, p. 128). Dentre esses problemas, a ganância sem limites, a violência urbana, o individualismo exacerbado, bem como outras situações citadas tanto em discursos simplórios e ingênuos, quanto em análises ditas sérias e sofisticadas.

O consumo moralista é a categoria que não vê o consumo com bons olhos, o recrimina, culpa o consumismo por diversos problemas e, como Rocha (2005), define, possui um "estilo apocalíptico" de ser.

Classificar alguém como bom trabalhador, produtivo, dedicado à empresa (ou até mesmo workaholic) é atribuir uma identidade positiva. Inversamente, classificar alguém como gastador ou consumista significa atribuir uma identidade negativa. (...)É como se a produção possuísse algo de nobre e valoroso, representando o mundo verdadeiro ou a vida levada a sério, e o consumo, no polo oposto, tivesse algo de fútil e superficial, representando o mundo falso e inconsequente (ROCHA, 2005, p. 129).

Isso porque um dos embates que melhor caracterizam essa visão está na comparação entre produção e consumo. A produção, bem como os temas que a ela se relacionam - como trabalho, profissão, empresa frequentemente são postos como superiores ao consumo e sua temática de marcas, gasto, compra. É a 
conhecida fábula da cigarra e da formiga: enquanto uma come, canta e gasta, a outra produz, poupa e trabalha.

\section{PROCEDIMENTO METODOLÓGICO}

\section{Semiótica Discursiva}

Também conhecida como Semiótica Francesa ou Greimasiana, a teoria que embasa os processos analíticos desta pesquisa foi fundada pelo lituano Algirdas Julian Greimas (1917-1992). Seu trabalho formou bases renovadoras para a semiótica, principalmente, a partir da década de 60 . O autor é responsável por desenvolver, dentre outros, os conceitos de semântica estrutural do texto, semiótica do mundo natural, organizados a partir de uma proposta metodológica denominada percurso gerativo de sentido. No trabalho aqui proposto, além de Greimas, autores como Diana Luz Pessoa de Barros, Lúcia Teixeira, José Luiz Fiorin, dentre outros, contribuem para a fundamentação teórico-metodológica da semiótica discursiva.

Definindo-se como teoria geral do texto e da significação, a semiótica ocupa-se da produção de sentido de um texto, considerando a articulação entre o plano de conteúdo e o plano de expressão da linguagem, bem como categorias gerais de análise capazes de contemplar a totalidade dos textos, manifestados em qualquer materialidade, bem como definir as estratégias enunciativas particulares utilizadas nos textos concretos (TEIXEIRA, 2009).

Segundo a autora, a semiótica concebe a produção de sentido em um texto como um percurso gerativo composto por três patamares: o fundamental, o narrativo e o discursivo. No fundamental, uma oposição abrangente e abstrata organiza o mínimo de sentido, a partir do qual o texto se articula. No nível narrativo, emergem sujeitos em busca de valores investidos em objetos, traçando percursos que expandem e complexificam as oposições do nível anterior. No patamar discursivo, um sujeito da enunciação converte as estruturas narrativas em discurso, por meio da disseminação de temas e figuras que constituem a cobertura semântica do mesmo. Uma vez que "o objetivo da teoria é construir um modelo capaz de prever uma gramática das relações entre sujeitos e entre sujeitos e objetos, manifestando-se nos textos como representação das interações do homem no mundo"(TEIXEIRA, 2009, p. 43), a relação entre a utilização da teoria e metodologia da semiótica discursiva para análises pertinentes ao consumo de bens, serviços e ideias é de extrema relevância para este campo de estudos, pois a partir de um suporte teórico fundamentado é possível desenvolver análises consistentes dos textos.

No nível fundamental, o mais profundo dos três níveis, encontram-se os valores, que são categorias semânticas que estão na base da construção de um texto. "Uma categoria semântica fundamenta-se numa diferença, numa oposição" (FIORIN, 2011, p. 21). Esses termos opostos, por exemplo, /sucesso/ versus /fracasso/, possuem uma relação de contrariedade entre si. Ainda, se aplicarmos uma operação de negação nesses termos, teremos os termos contraditórios: /não sucesso/ é o contraditório de /sucesso/ e /não fracasso/ é o contraditório de /fracasso/.

A semiótica parte dessa visão espetacular da sintaxe e propõe duas concepções complementares de narrativa: narrativa como mudança de estados, operada pelo fazer transformador de um sujeito que age no e sobre o mundo em busca dos valores investidos nos objetos; narrativa como sucessão de estabelecimentos e de rupturas de contratos entre um destinador e um destinatário, de que decorrem a comunicação e os 
conflitos entre sujeitos e a circulação de objetos. As estruturas narrativas simulam, por conseguinte, tanto a história do homem em busca de valores ou à procura de sentido quanto a dos contratos e dos conflitos que marcam os relacionamentos humanos (BARROS, 2002). Nesse sentido, a lógica do consumo se aproxima da semiótica, na medida em que sujeitos e objetos interagem, em busca de valores como reconhecimento, diferenciação, pertencimento, hedonismo, dentre outros.

$\mathrm{Na}$ análise semiótica do texto, identificam-se enunciados de estado e enunciados de fazer. Os primeiros são a relação de junção entre o sujeito e os objetos do texto, enquanto os segundos são a transformação operada pelo sujeito em relação aos objetos. Ainda, a junção é a relação que determina o estado, a situação do sujeito em relação a um objeto qualquer, podendo relacionar-se em conjunção ou disjunção. "O objeto, enquanto objeto sintático é uma espécie de casa vazia, que recebe investimentos de projetos e de determinações do sujeito. Os investimentos fazem do objeto um objeto-valor e é, assim, por meio do objeto que o sujeito tem acesso aos valores" (BARROS, 2002, p. 19). Ainda, nos textos, os elementos semânticos podem assumir valores disfóricos (negativos) ou eufóricos (positivos), dependendo da narrativa em que estão inseridos (FIORIN, 2011). No consumo, os bens (objetos) também carregam significados em relação ao grupo de referência a que se deseja atingir. Consumir determinados acessórios de grife, como bolsas, sapatos, relógios, por exemplo, funcionam como ferramenta de marcação para um grupo em questão, que reconhece nesses objetos valores compartilhados entre o grupo (poder, status, riqueza).

Esses enunciados de estado e de fazer se organizam em narrativas complexas. A sequência canônica de uma narrativa complexa engloba quatro fases: a manipulação (que pode ser por tentação, intimidação, sedução ou provocação), a competência (em que o sujeito que vai realizar a transformação central da narrativa é dotado de um saber e/ou poder-fazer), a performance (fase em que se dá a transformação mudança de estado - central da narrativa), e a sanção (constatação de que a performance se realizou), em que, eventualmente, são distribuídos prêmios e castigos (FIORIN, 2011).

\section{Corpus de análise}

A pesquisa original a que este artigo se refere possui como universo um total de 36 revistinhas TMJ, publicadas, mensalmente, nos anos de 2012-2013-2014. Desse total, mais da metade delas -22 revistas $(61,1 \%)$ - tiveram o consumo como temática central da história apresentada, condição necessária para compor a amostragem do estudo. Das quatro categorias analisadas, o consumo moralista, temática de que se trata este artigo, esteve presente em três revistas, representando um total de 13,6\%.

Dentre as três revistas categorizadas como consumo moralista, o recorte aqui proposto corresponde à edição n 58 de TMJ, intitulada "Conflito de Gerações", publicada em maio de 2013. 


\section{ANÁLISE SEMIÓTICA}

Em TMJ n 58 - "Conflito de Gerações" - Cebola fica com ciúmes ao ver Mônica toda derretida por Toni, que acaba de ser escolhido como garoto propaganda de uma marca de refrigerantes e tem sua imagem estampada em outdoors pela cidade. Após discutir com o concorrente pela atenção de Mônica, Cebola aceita passar uma noite, sem a ajuda de ninguém, no Monte do Desafio. A fim de entendermos melhor o que essa provocação representa na história, é preciso analisar o perfil dos personagens envolvidos.

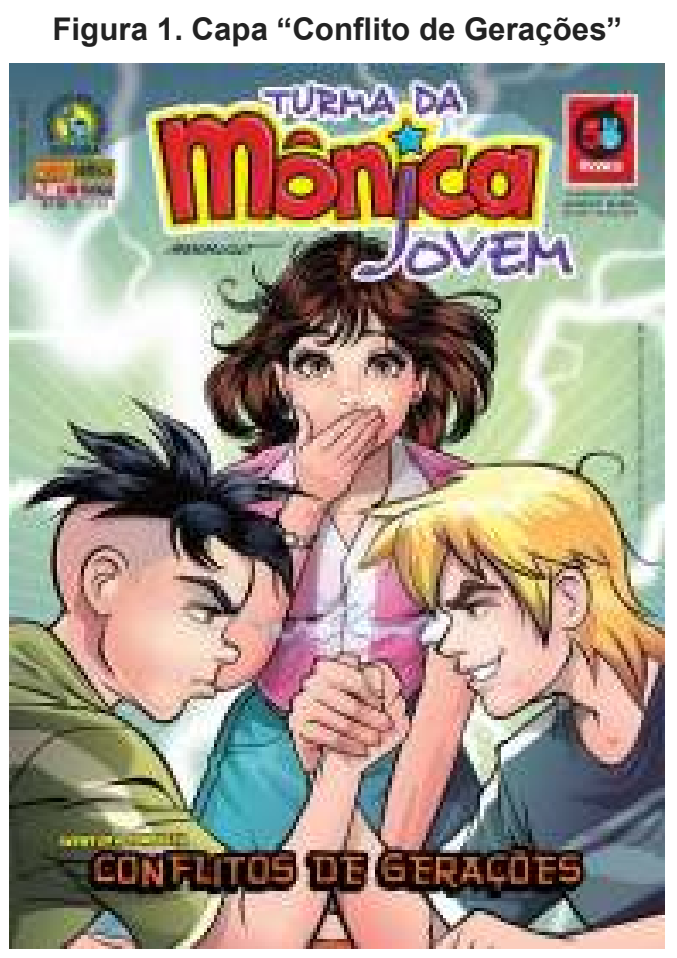

Fonte: Sousa (2013).

Cebola pode ser considerado a versão masculina nerd da turma, apesar de não gostar muito desse rótulo. Desde criança, uma de suas características principais, como ele mesmo diria, era traçar planos infalíveis para conquistar o mundo. É considerado inteligente pelos outros colegas e pouco interessado em praticar esportes, muito menos os ditos "radicais". É apaixonado pela Mônica, mas vivem uma relação conturbada, cheia de altos e baixos. Continua tendo pouco cabelo, apesar de não ser mais apenas cinco fios, e só fala "elado", trocando o erre pelo ele, quando está nervoso. 
Figura 2. Cebolinha e seus planos infalíveis

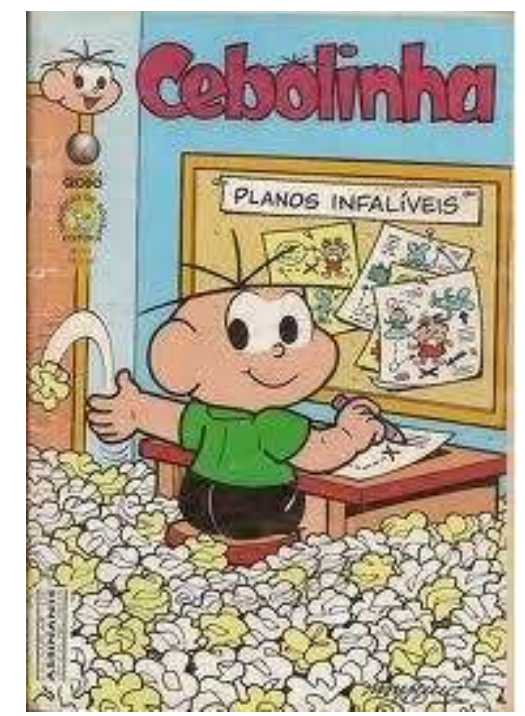

Fonte: WIKIA, acesso em 06 maio 2014.

Esquema 1: Isotopia temática Cebola - nervoso, inteligente, apaixonado, cheio de planos infalíveis para conquistar a Mônica e o mundo.

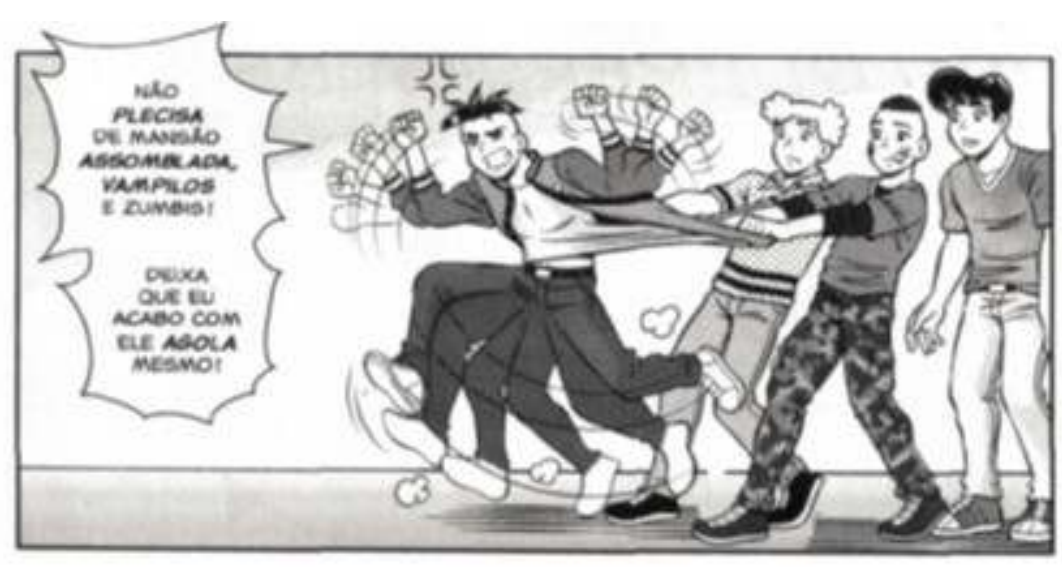

continua

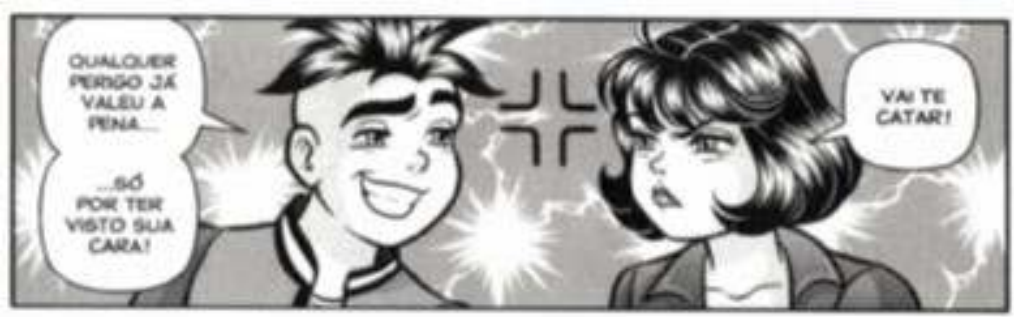

TMJ $68-$ p. 38

Cebola nervoso.

TMJ 68 - p. 52

Implicante com a Mônica. 
Esquema 1: Isotopia temática Cebola - nervoso, inteligente, apaixonado, cheio de planos infalíveis para conquistar a Mônica e o mundo.
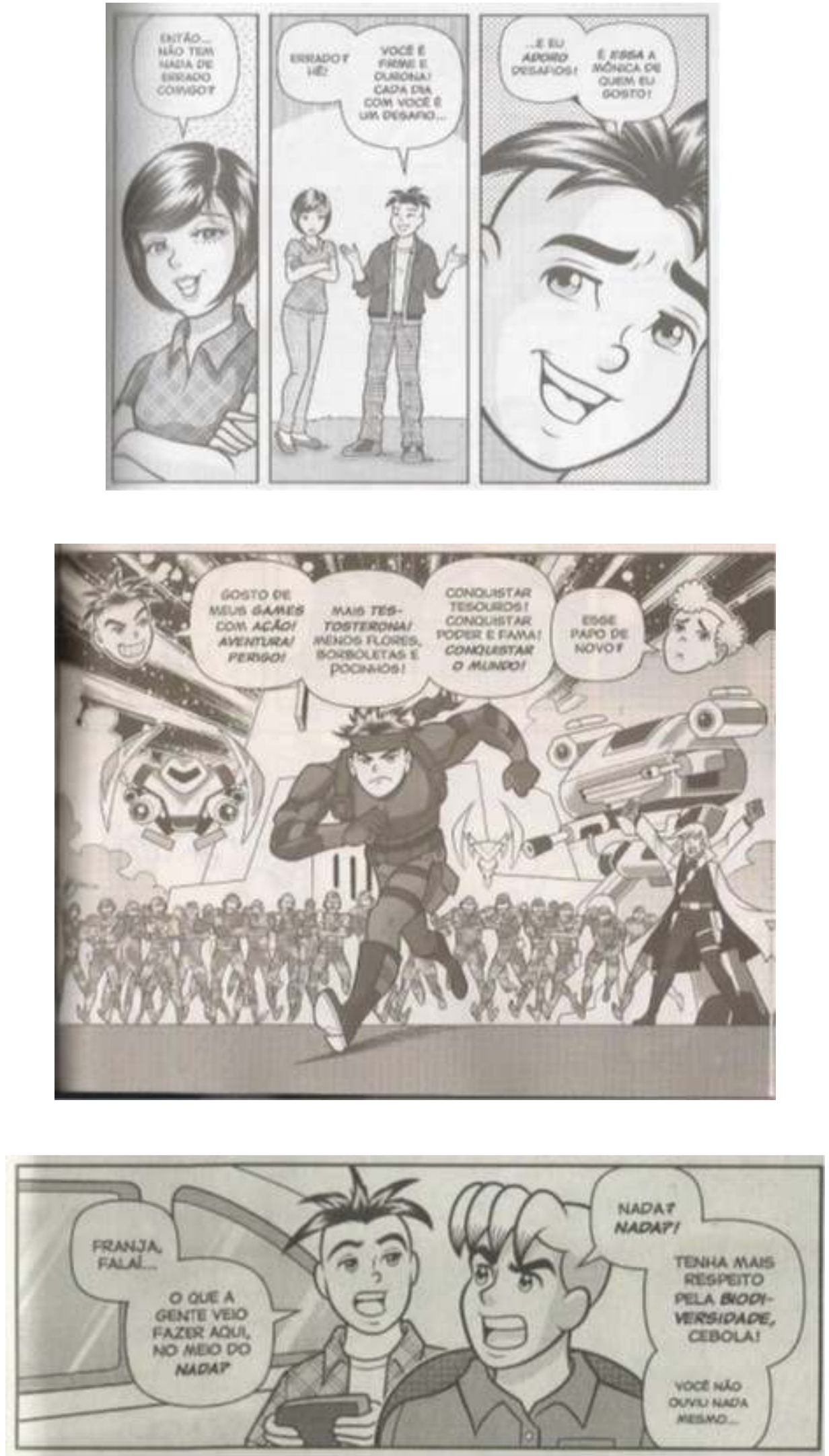

continua

TMJ 61 - p. 123

Apaixonado pela Mônica.

TMJ 59 - p. 17

Planos para conquistar o mundo.

TMJ 43 - p. 10

Cebola Tecnológico-

desinteresse por assuntos da natureza. 


\section{Esquema 1: Isotopia temática Cebola - nervoso, inteligente, apaixonado, cheio de planos infalíveis para conquistar a Mônica e o mundo.}
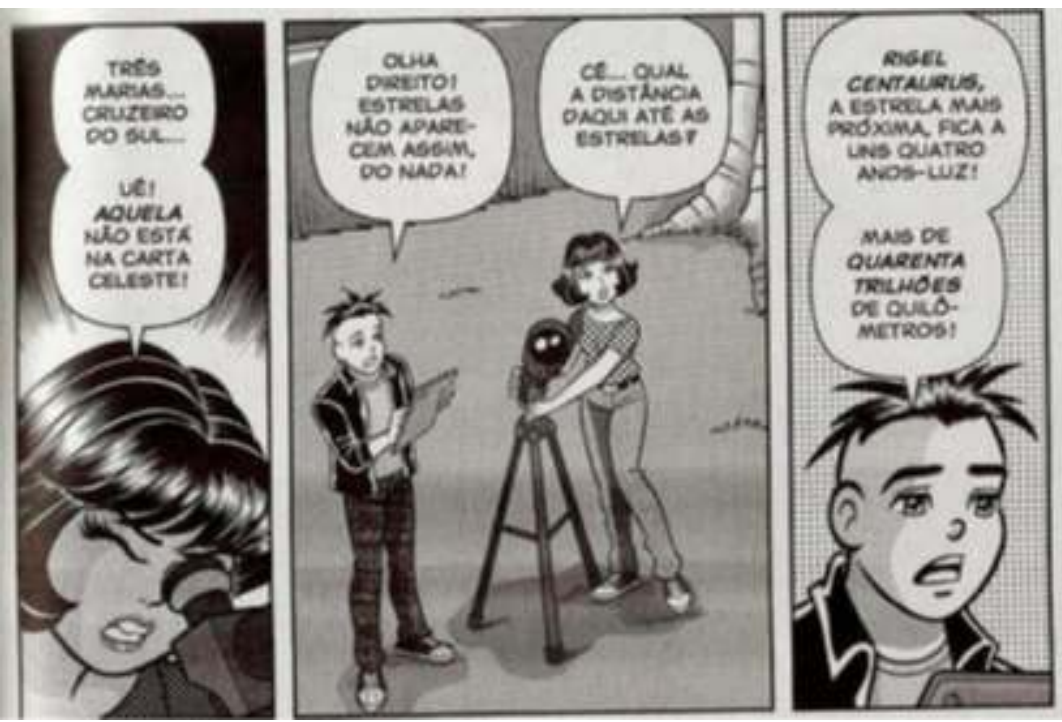

continuação

Fonte: Elaborado pelas autoras.

Toni, conhecido como Tonhão da rua de baixo (nas histórias da Turma da Mônica tradicional) é um rapaz bonito, atraente, que gosta de praticar esportes, sendo figurativizado com cabelos mais compridos que os demais garotos, roupas e outros traços que produzem efeitos de sentido de um visual mais despojado, estilo surfista. Apesar de não mais usar de violência contra seus colegas, como fazia na infância, é considerado mentiroso, mau caráter e pouco confiável, pelos demais colegas. Em outras histórias, já teve momentos de envolvimento com a Mônica, tentando conquistar o coração da escolhida de Cebola.

Esquema 2: Isotopia temática Toni - agressivo, mau caráter, mentiroso.

continua

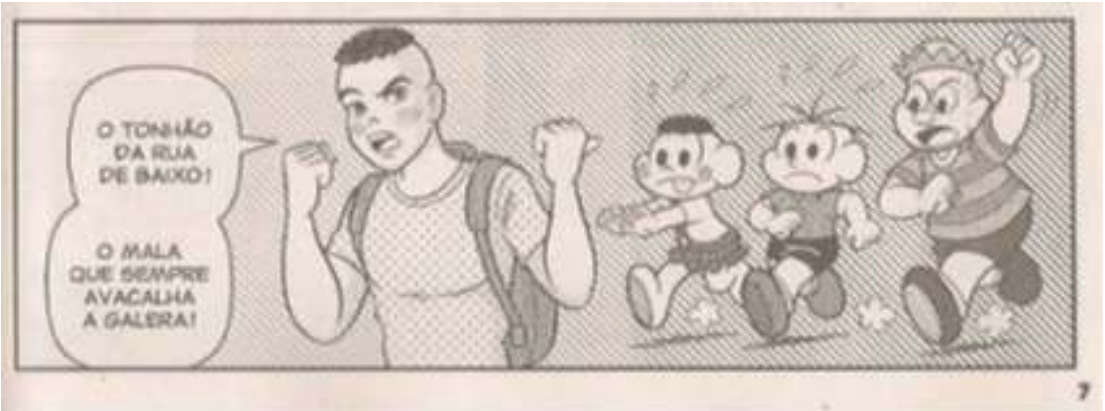

TMJ $58-$ p. 7

Toni, por Cascão.

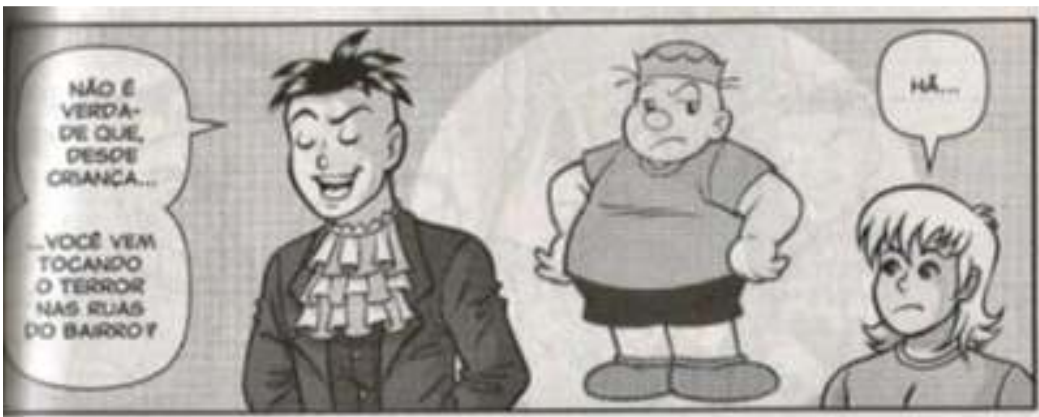

TMJ 62 - p. 51

Toni, por Cebola. 
Esquema 2: Isotopia temática Toni - agressivo, mau caráter, mentiroso.

continua

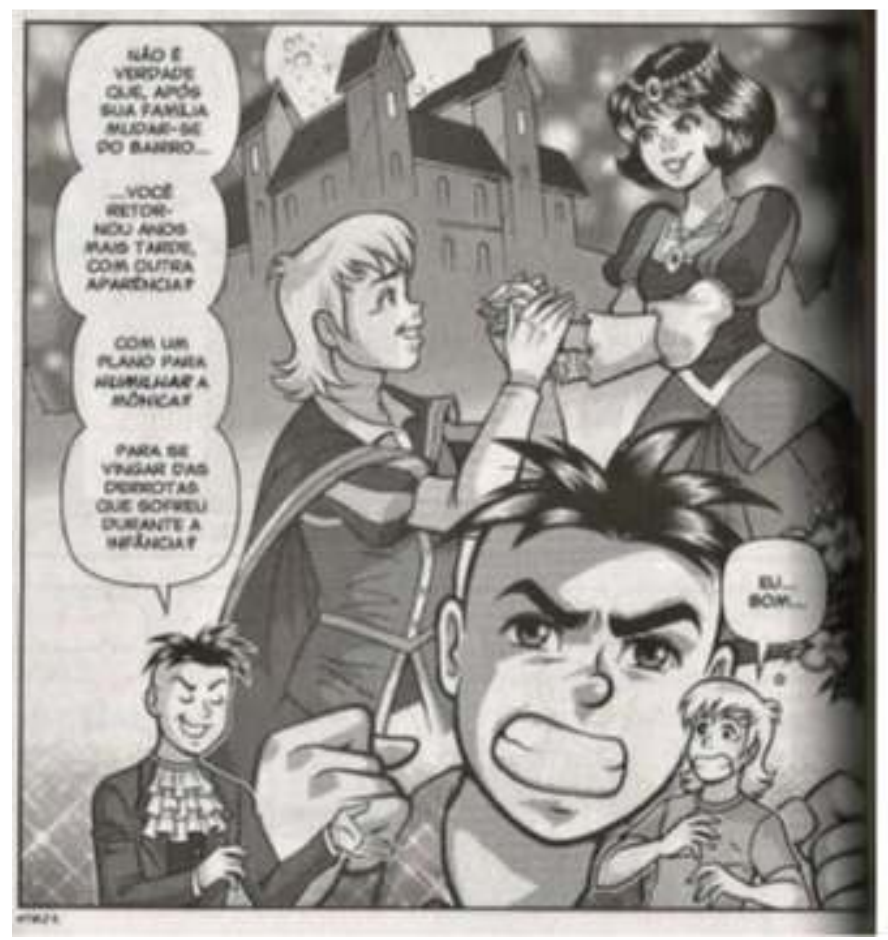

TMJ 62 - p. 52

Toni, o enganador.

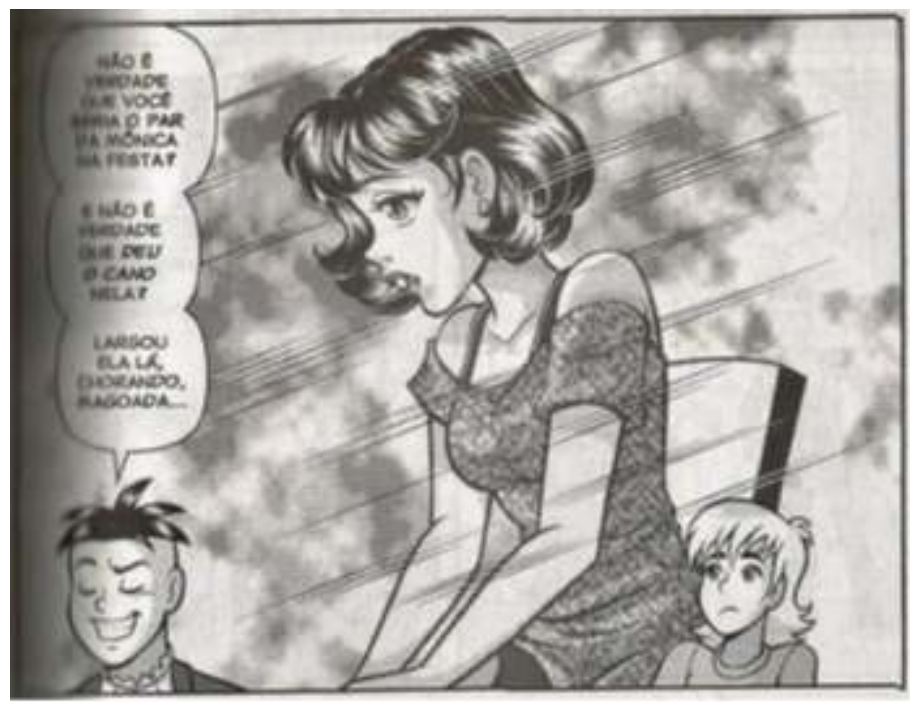

TMJ 62 - p. 53

Toni, o sem palavra.

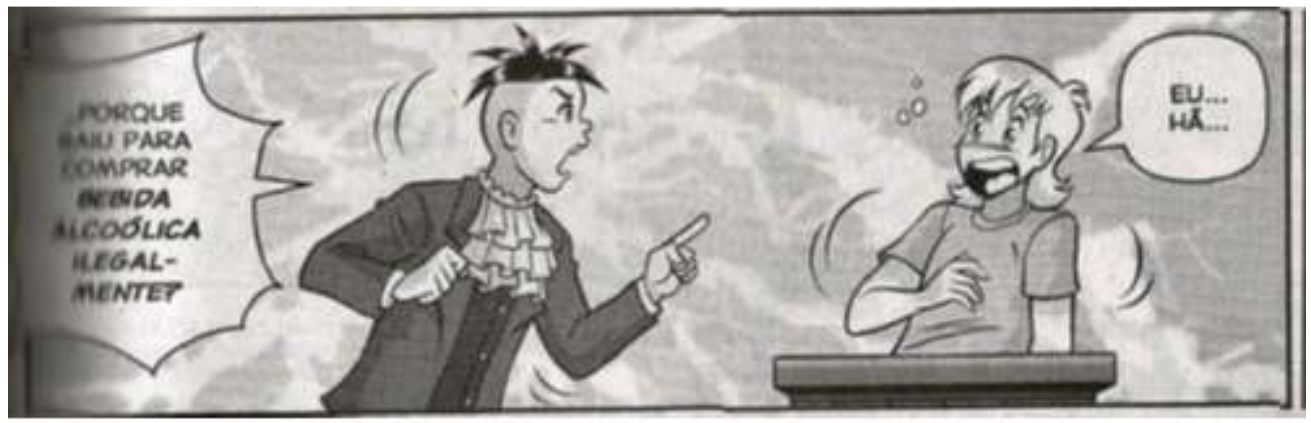

TMJ 62 - p. 53

Toni, o fora da lei. 
Esquema 2: Isotopia temática Toni - agressivo, mau caráter, mentiroso.

continuação
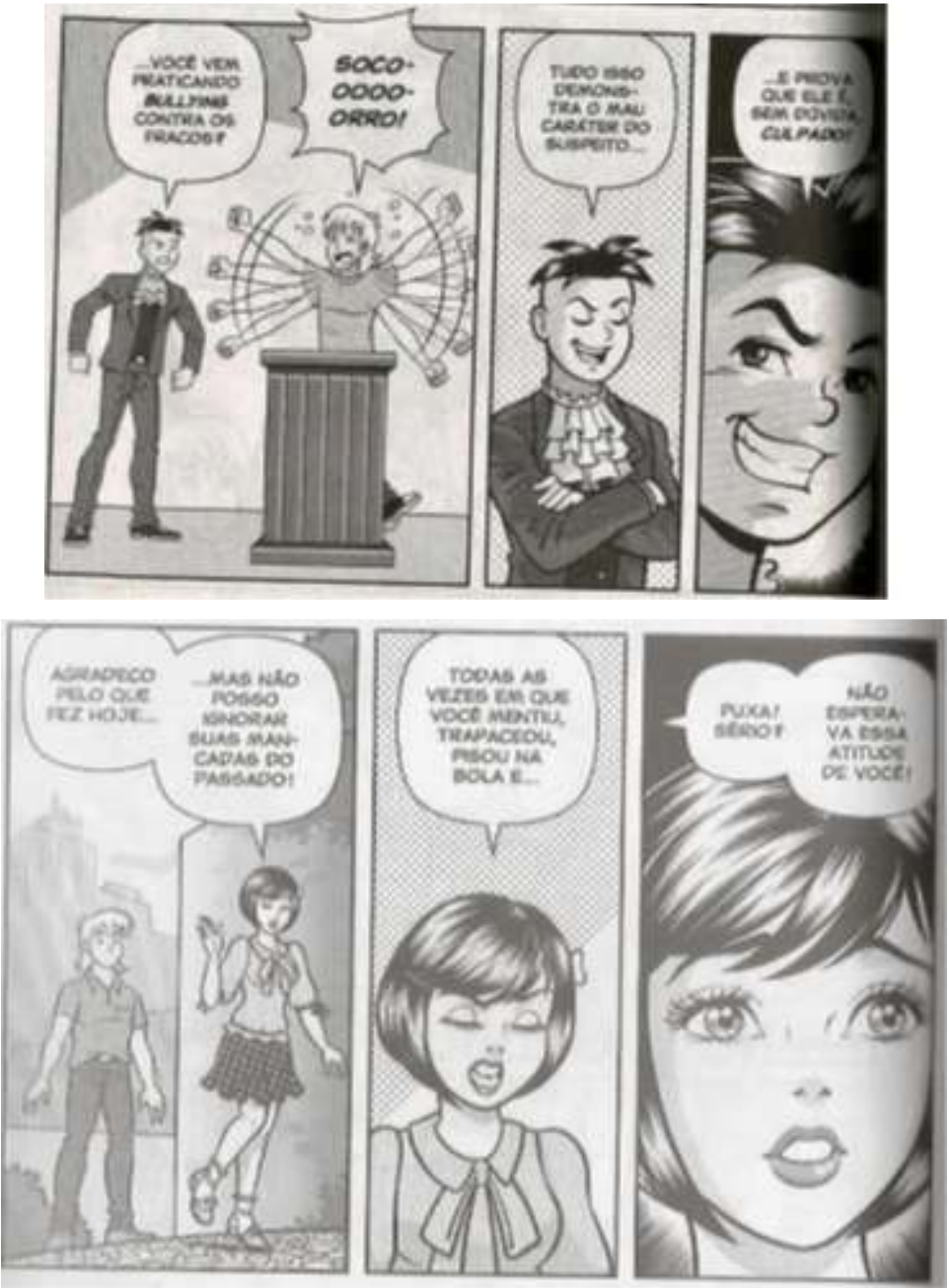

TMJ 62 - p. 54

Toni, o agressivo.

TMJ 61 - p. 92

Toni por Mônica.
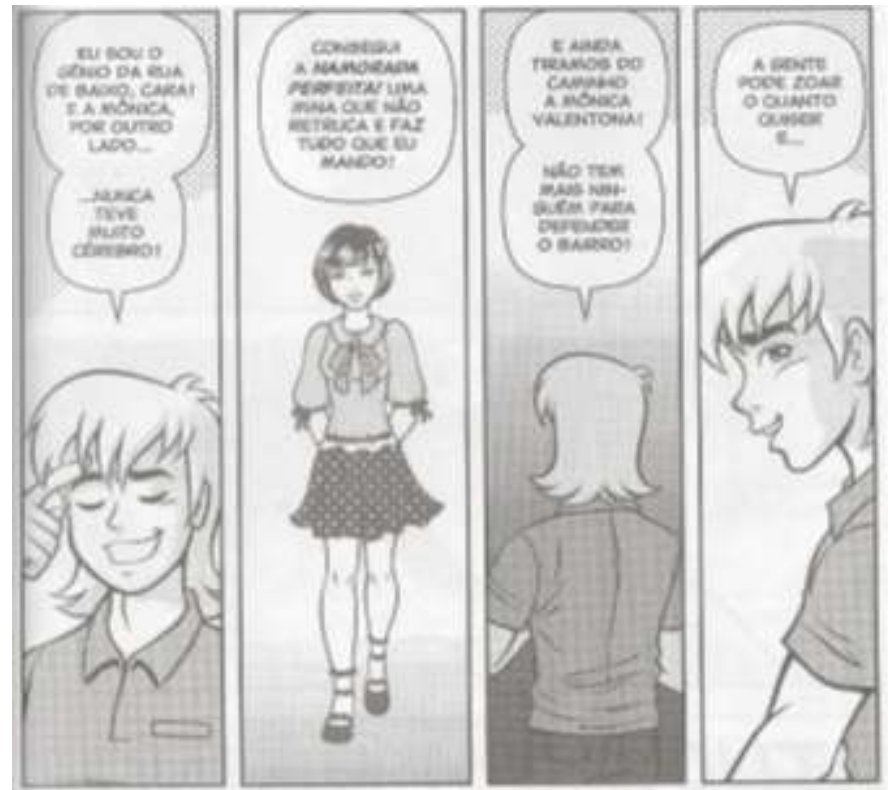

TMJ $61-$ p. 111

Toni por Toni.

Fonte: Elaborado pelas autoras. 
A primeira página da história (figura 3), mesmo antes de introduzir o conflito, já é uma provocação ao personagem Cebola. A figura de Toni, descendo de rapel um prédio alto, em meio a uma cidade movimentada, está centralizada na página. A frase "Ele vai conquistar o MUNDO!" aparece no topo, centralizada e em negrito, com a palavra mundo destacada das demais por estar em letras maiúsculas. Para os leitores da Turma da Mônica e Turma da Mônica Jovem, mesmo não trazendo a figura do personagem Cebola nesta página, a mensagem é bem clara: não é Cebola quem vai conquistar o mundo, mas Toni, ou seja, o conflito entre os dois personagens é certo, na história que está por começar.

Figura 3. Toni vai conquistar o mundo

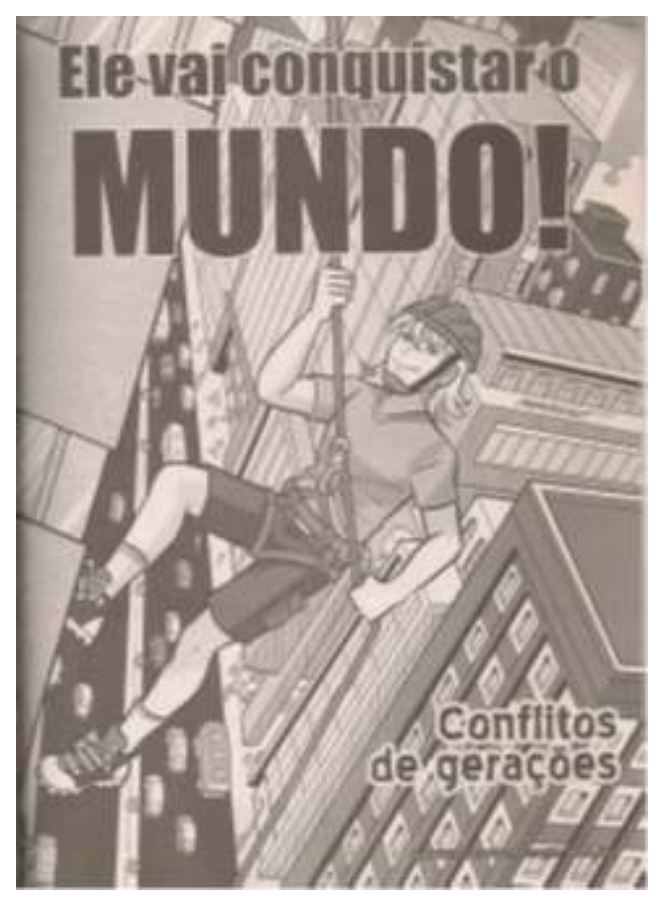

Fonte: Sousa (2013, p. 5.)

O primeiro programa narrativo da trama gira em torno da fama, do mundo das celebridades, do popular. Nesse contexto, ninguém melhor que a personagem Denise para personificar essa atração pelo que é famoso. A personagem aparece em situações de deslumbre (ora com os braços erguidos e abertos, ora com os olhos vidrados em formato de estrela) e descreve, por meio de palavras como "meteoricamente", "astro", bem como outros argumentos, a importância de ser o garoto propaganda de uma marca de refrigerantes, como o Toni. Diferente dela, os outros personagens da cena, Cascuda, Magali e Cascão, não demonstram a mesma empolgação com a fama do colega (suas posturas e expressões são quase apáticas). 
Figura 4. Denise deslumbrada 1

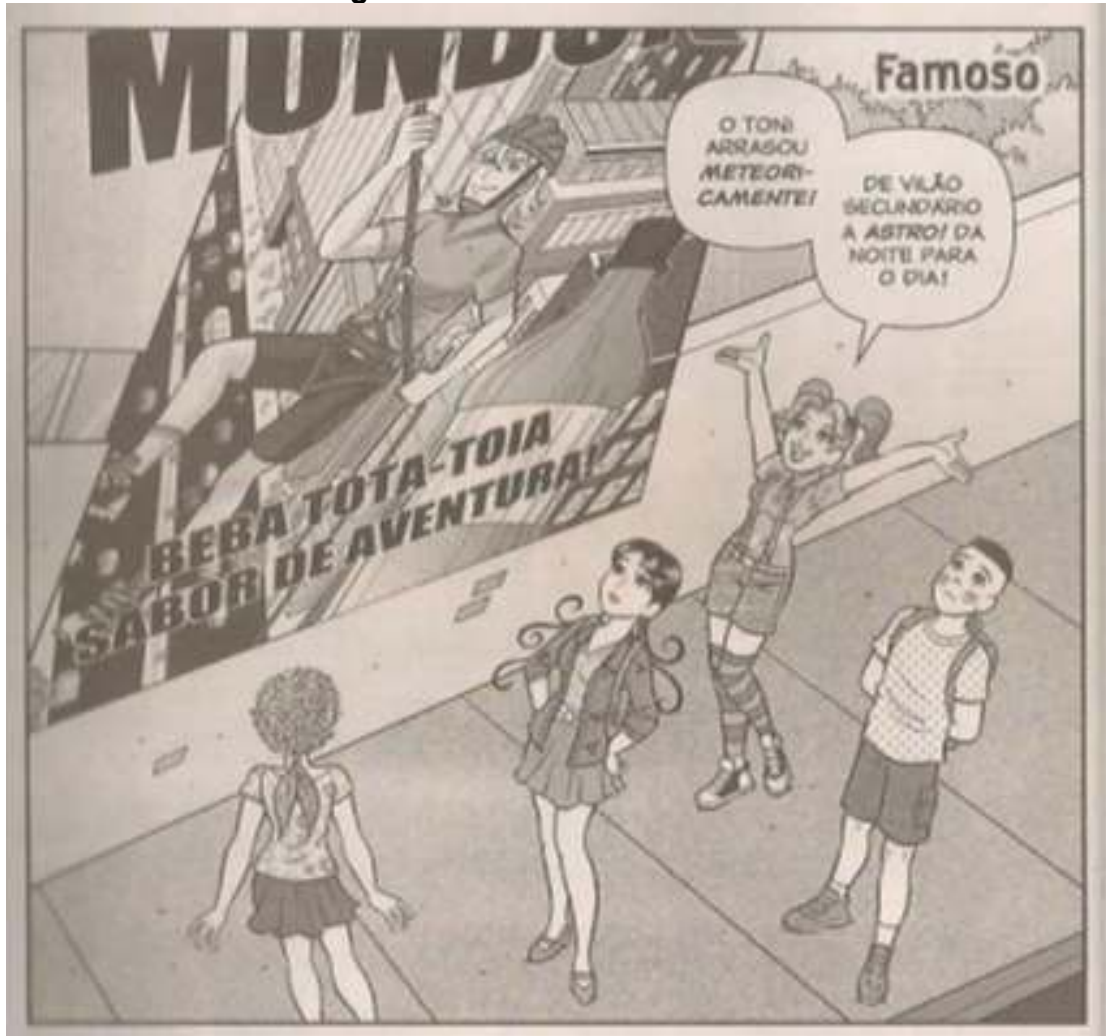

Fonte: Sousa (2013, p. 6)

Figura 5. Denise nervosa com a pouca importância dada por Magali ao fato

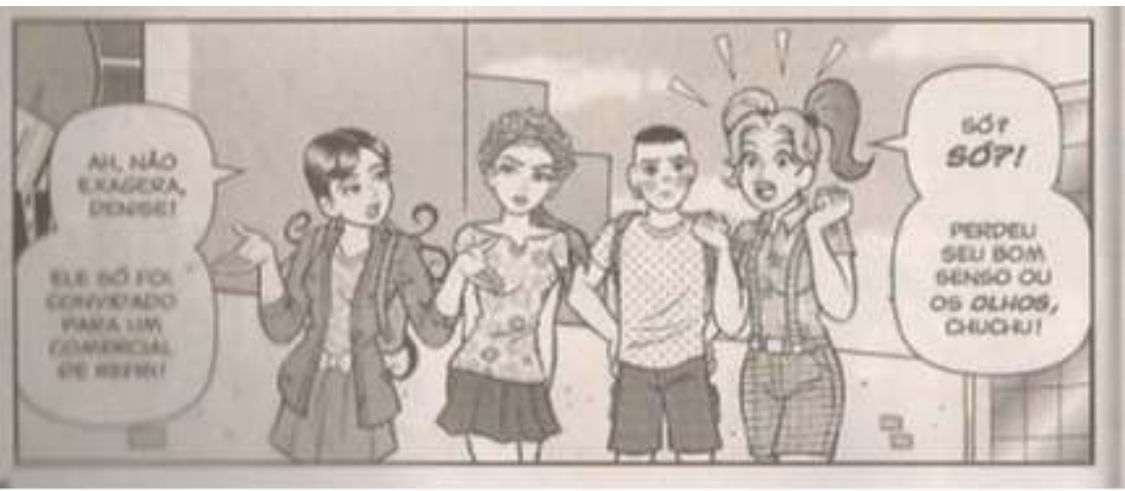

Fonte: Sousa (2013, p. 6)

Figura 6. Denise deslumbrada 2

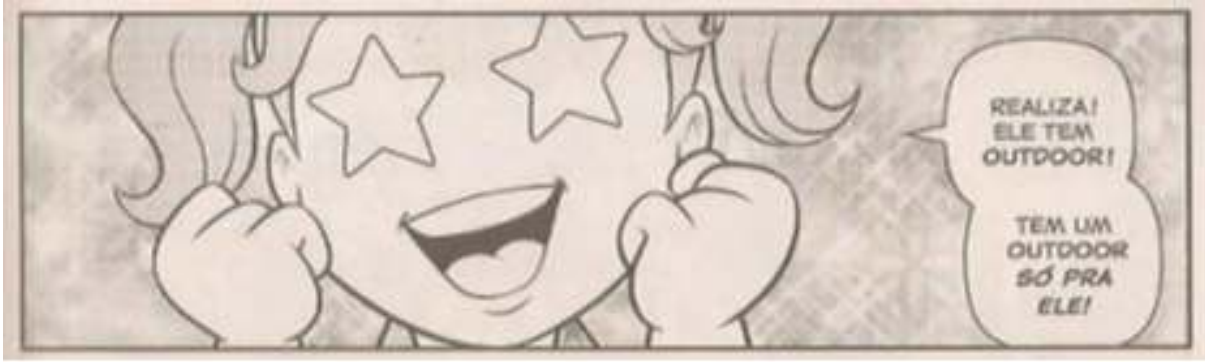

Fonte: Sousa (2013, p. 7) 
Podemos perceber várias referências ao mundo da propaganda (outdoor), das marcas (Coca-Cola), da divulgação nas redes sociais (tumbler), o que representa a cultura de consumo midiático típica dos adolescentes da sociedade contemporânea.

Figura 7. Denise querendo aparecer diante da fama do colega

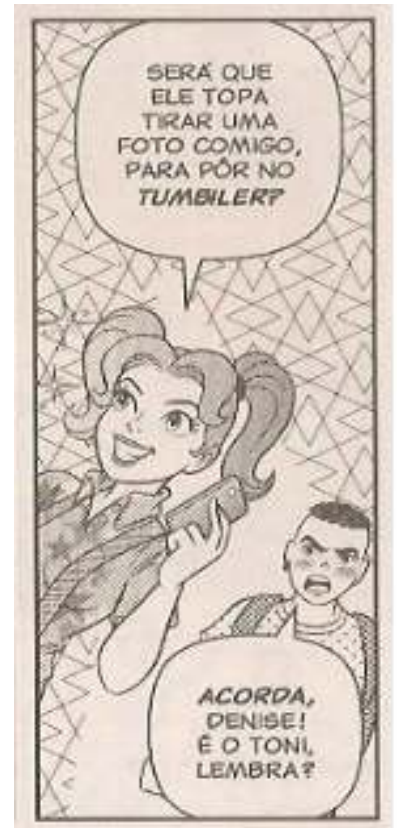

Fonte: Sousa (2013, p. 7)

Assim, nesse programa narrativo, temos Toni, o sujeito de estado que entra em conjunção com o objeto "fama", saindo do anonimato, a partir do momento em que aparece na propaganda de uma marca de refrigerante. Denise, por meio de manipulação por tentação (se você for amigo do Toni, vai ser famoso como ele ou vai colher os benefícios dessa fama), tenta convencer a todos da importância da fama do Toni para eles, mudando a percepção negativa que eles têm do colega. Entretanto, Cascão e Magali tentam lembrar a Denise quem realmente é o Toni, alguém que sempre foi motivo de discórdia para a turma.

Figura 8. Argumentação Magali 1

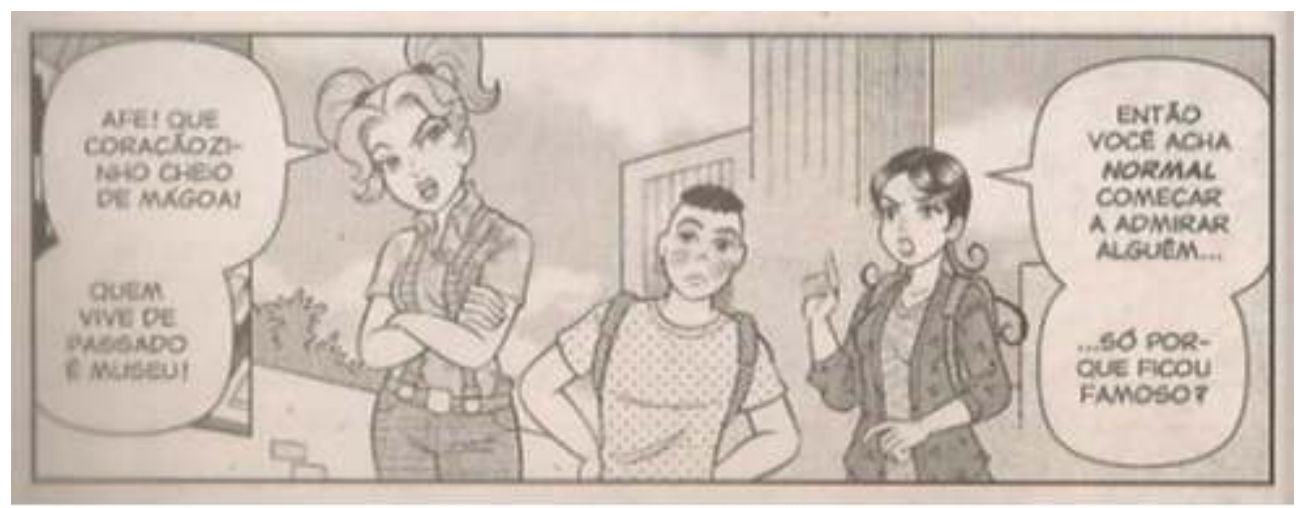

Fonte: Sousa (2013, p. 8) 
Figura 9. Argumentação Magali 2

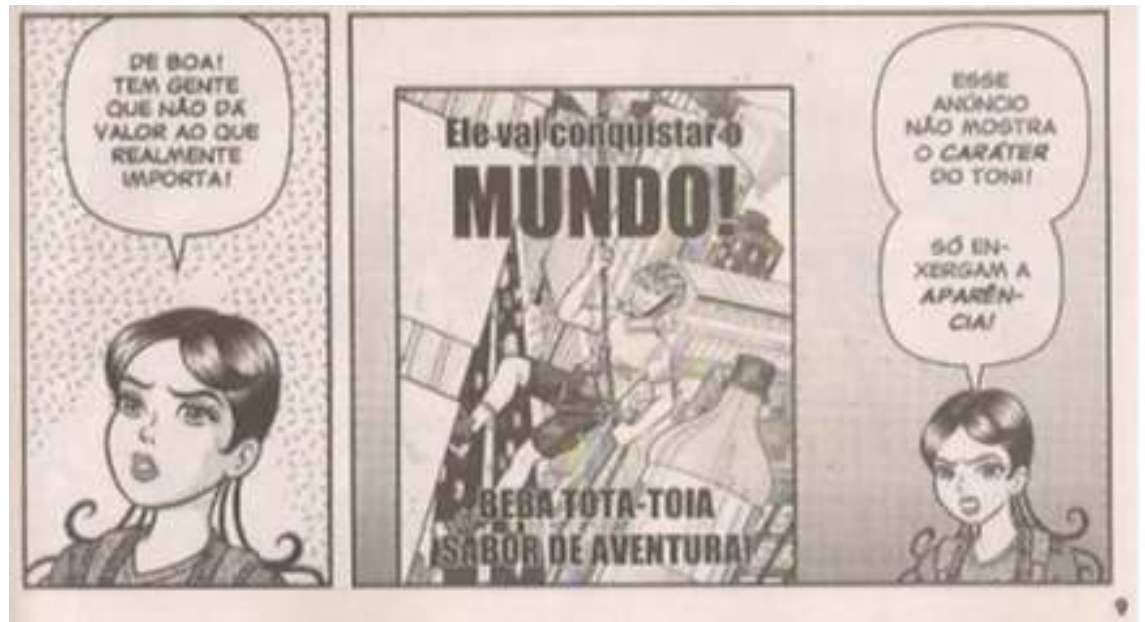

Fonte: Sousa $(2013$, p. 9)

Assim, Denise não apresenta a competência necessária para transformar a imagem de mau caráter de Toni, não conseguindo realizar a performance deste primeiro programa narrativo. O que podemos pensar é que os valores são diferentes para esses personagens. Para Toni e Denise, o /sucesso/ é o objeto valor desejável, portanto, eles compartilham os mesmos valores. Para os demais, os valores são outros. Trata-se de uma narrativa passional (a inveja é uma paixão), pois é movida pelo "querer ser", no primeiro caso (o desejo, a ambição), enquanto que, para os demais personagens envolvidos (Magali, Cebola, etc), trata-se do "querer-não-ser", ou seja, os valores em jogo são o /desprendimento/ e a /generosidade/.

A partir do momento em que Cebola entra na história, irritado com a atenção que Mônica dá para Toni, as isotopias do nerd, dessa vez, reiterada no personagem Cebola, e do bonito e popular, representado por Toni, são colocadas em comparação, por meio do discurso dos personagens. Figurativamente, Toni é mostrado sempre muito confiante de si, com sorriso largo no rosto e gestos que demonstram tranquilidade diante das provocações do "rival" (Figuras 10, 13 e 14). Em alguns momentos, os contornos de seu personagem aparecem ultrapassando os limites do quadrinho (Figura 14), realçando esse excesso de autoestima. Já Cebola, é figurativizado ora como um rapaz nervoso, desconfiado, com as sobrancelhas arqueadas, punhos cerrados, expressão de raiva (Figuras 10, 11 e 14), ora como uma pessoa mais inflamada, exagerada, como um nerd empolgado com suas descobertas (Figuras 11 e 12). Nesse ponto, continua a batalha entre os valores /aparência/ e /conteúdo/ (Figura 11 e 13). 
Figura 10. Provocação Toni

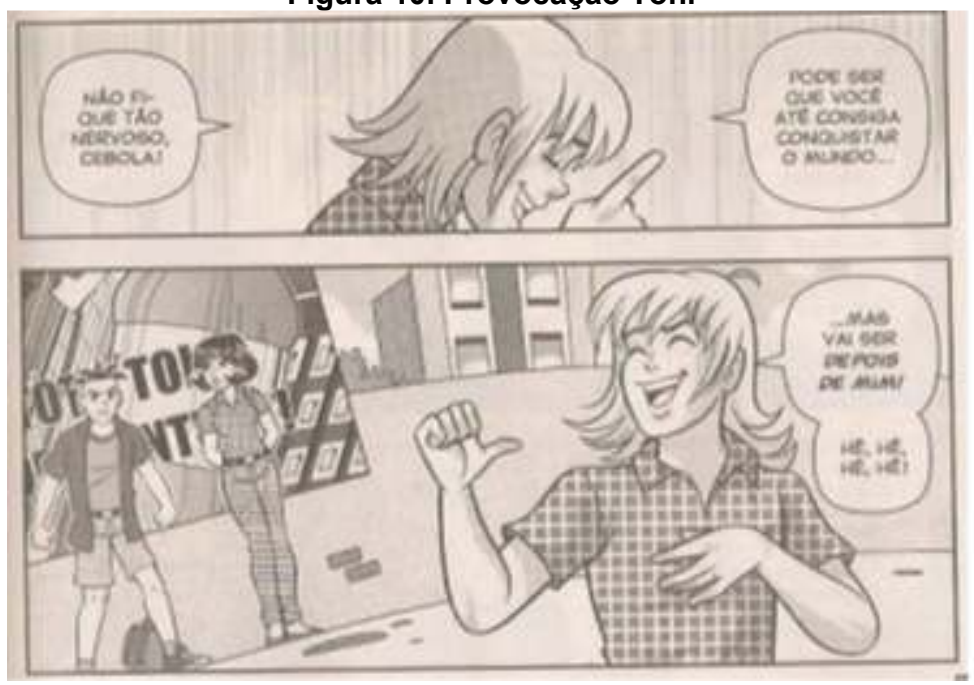

Fonte: Sousa (2013, p. 15)

Figura 11. Aparência x Conteúdo
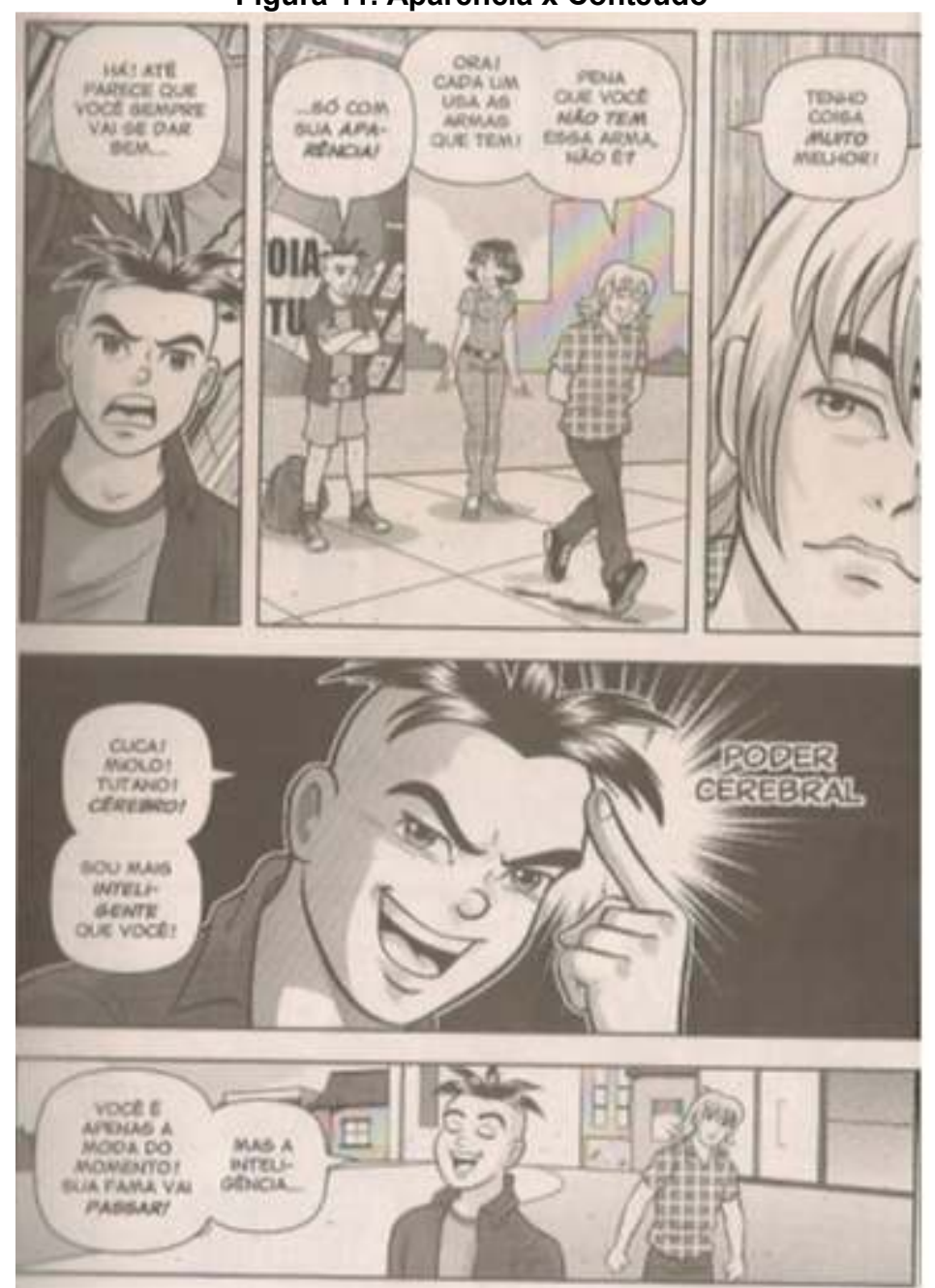

Fonte: Sousa (2013, p. 16) 
Figura 12. Cebola "inflamado"

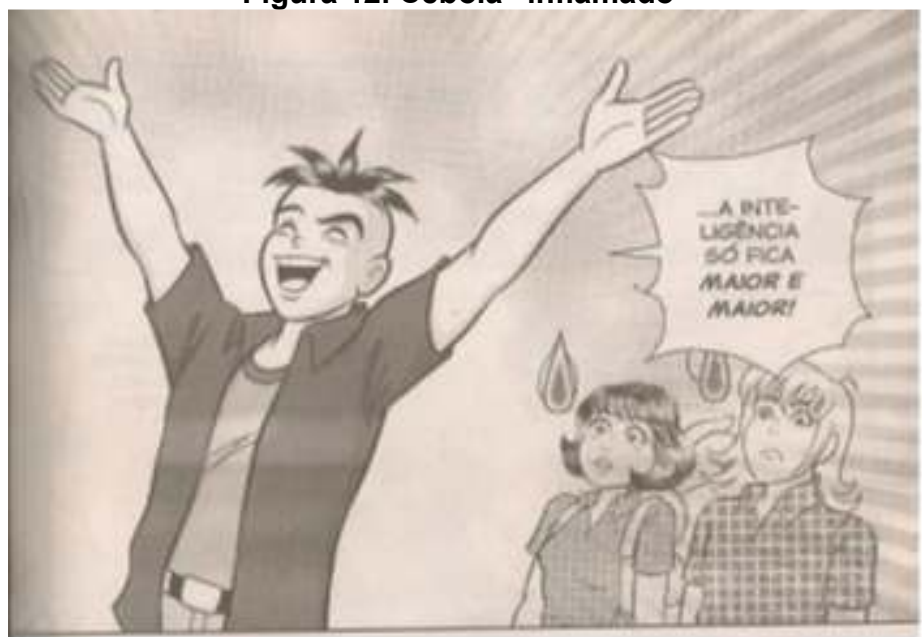

Fonte: Sousa (2013, p. 17)

Figura 13. Provocação Toni 2

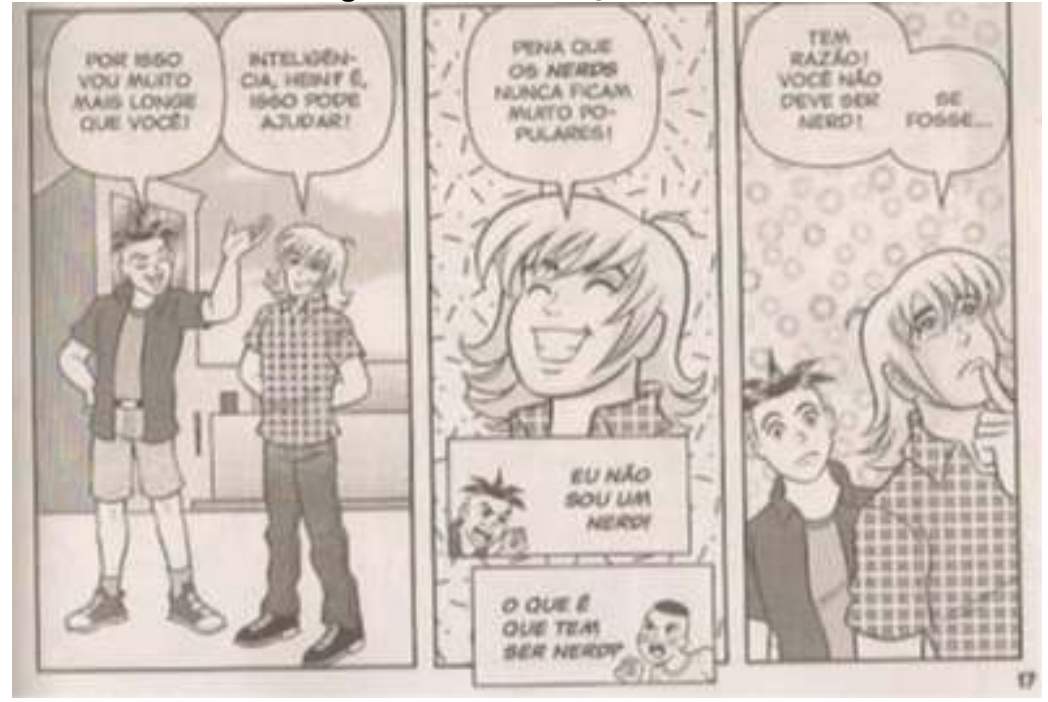

Fonte: Sousa (2013, p. 17)

Figura 14. Provocação Cebola

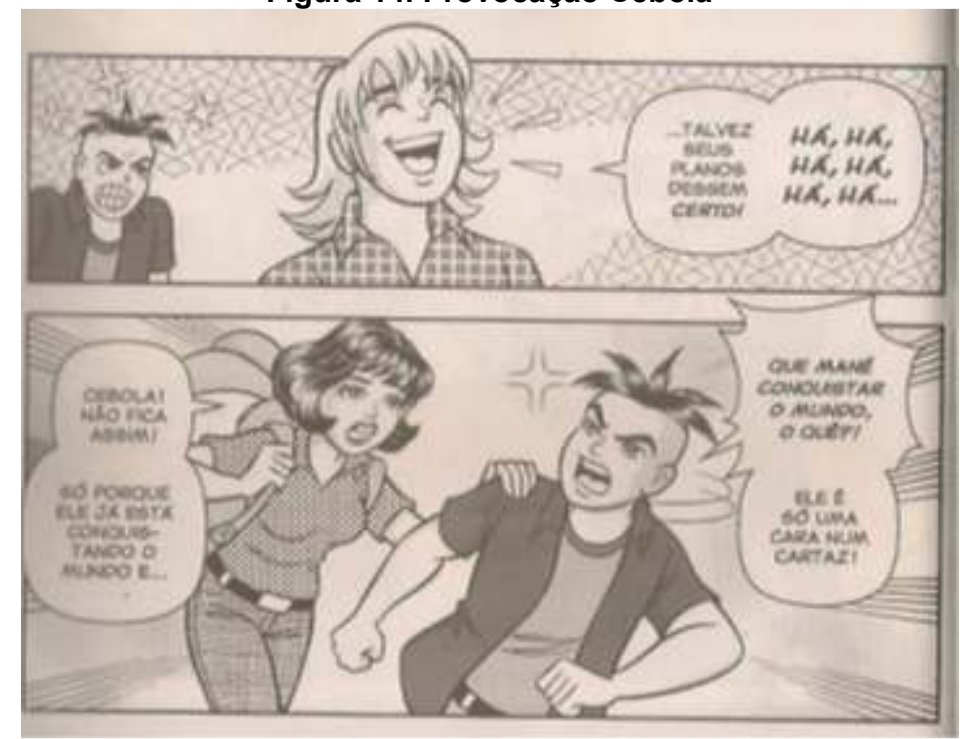

Fonte: Sousa (2013, p. 18) 
O segundo programa narrativo traz para o discurso a importância da mídia. Nele, esta aparece como sinônimo de parceria, confiança, informação certa, que não te abandona, quando o restante o faz. Após aceitar a provocação de Toni para passar uma noite sozinho, no "Monte do Desafio", Cebola, que não possui nenhum conhecimento de sobrevivência na selva, decide se preparar buscando ajuda no reality show "À prova de mato". Aqui, podemos identificar uma intertextualidade com a mídia atual e programas televisivos, como o norte-americano Survivor e sua cópia brasileira No Limite, além de outros programas do gênero, não necessariamente reality shows, transmitidos nos canais de TV por assinatura, principalmente.

Segundo Rocha e Pereira (2009, p. 10), a ideia de jovem e juventude foi concebida como um lugar transitório, entre uma "maturidade adiada e uma infância espremida", sendo, portanto, mediadora de diferenças entre diversos estados. Por esse motivo, a adolescência é entendida como um "rito de passagem", em que suas diferentes classificações são tratadas no gerúndio: formandos, vestibulandos, conforme o autor, a marca central do jovem.

Mediação que se dá entre coisas novas e velhas, antigas ideologias e projetos de vanguarda, sólidas certezas e modernas experiências, a vida que se passa na esfera da casa e da família e a vida que se passa além dela (ROCHA; PEREIRA, 2009).

Nesse período, os jovens passam por um processo constante de mediações entre valores, gostos, hábitos, estéticas, práticas sociais e atitudes, que acontecem, inclusive, entre modos de consumo, uso e valorização de novas tecnologias, adoção de costumes entre a infância e a idade adulta, entre a família e o mundo externo (ROCHA; PEREIRA, 2009).

Nesse contexto, a mídia enaltece o papel dos jovens e adolescentes, na sociedade vigente, como um forte mediador de inovações tecnológicas e modos de consumo, dentro do núcleo familiar; um papel fundamental, em um mundo repleto de tablets, celulares, computador, entre outros gadgets encontrados, no mercado.

Assim, temos um enunciado de fazer em que o objeto valor desejado pelo sujeito de estado Cebola é a informação. Cebola pretende entrar em conjunção com os conhecimentos de sobrevivência na selva e é manipulado pelo sujeito mídia que, por provocação (Você é capaz de comer minhoca para sobreviver?), age sobre o espectador, levando-o a crer que possui a competência necessária para realizar a performance de transmitir informação de qualidade que vai "salvar" a vida de Cebola, durante a estadia no Monte do Desafio.

Figurativamente, temos um Cebola pensativo, no primeiro quadro (Figura 15), que apresenta expressão de quem tem uma "grande ideia". A frase do personagem enfatiza seu sentimento de abandono, de estar sozinho nessa "grande roubada". Ele está em casa, vendo TV - que representa a companhia, nesse momento de solidão - e também a solução para seus problemas (substituindo a informação confiável de pais, amigos ou outras pessoas com experiência no assunto). A competência da mídia é reafirmada, no terceiro e quarto quadros da página seguinte (figura 16), bem como sua autossuficiência. 
Figura 15. Segundo programa narrativo: mídia.

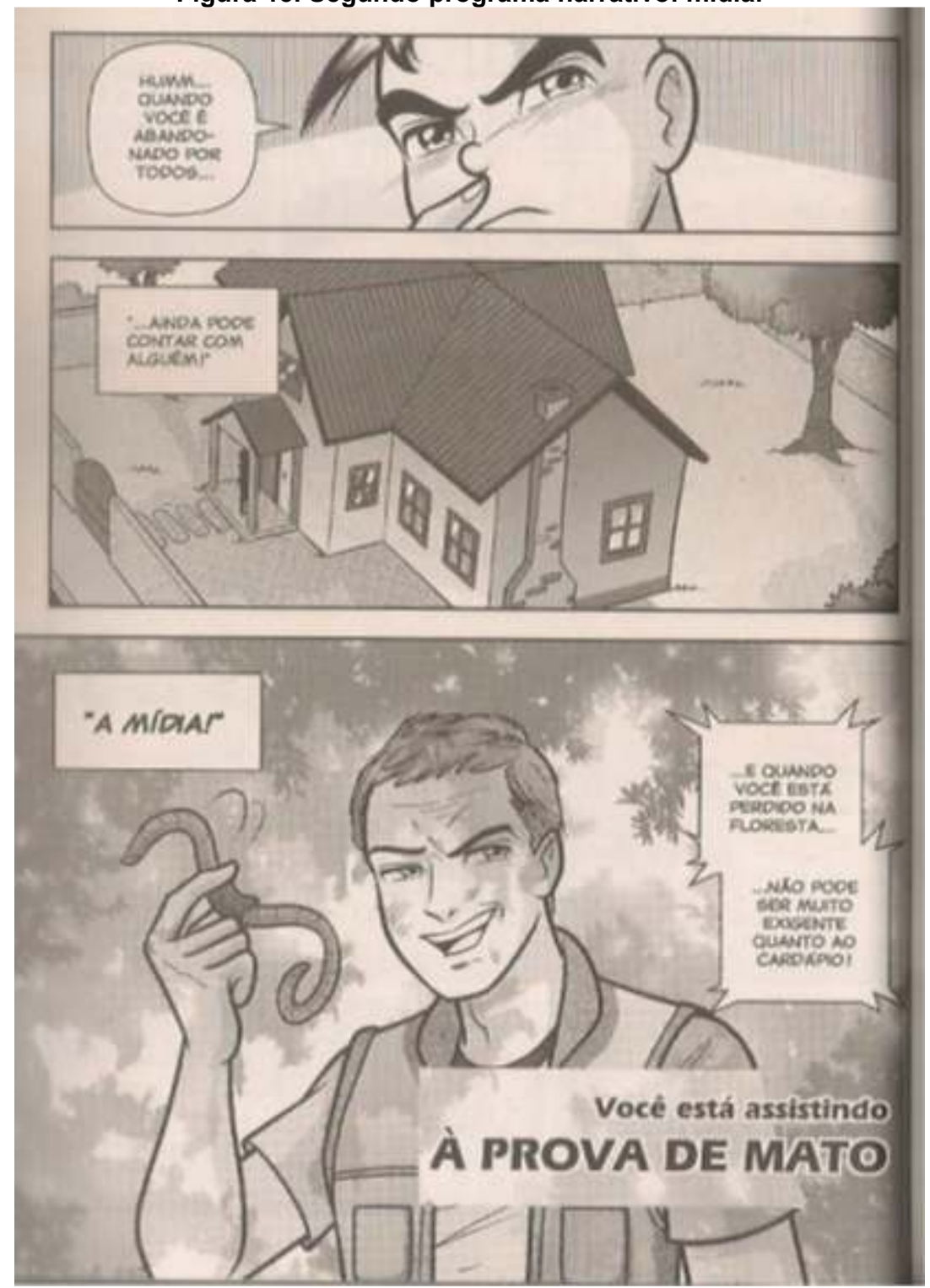

Fonte: Sousa (2013, p. 32)

Figura 16. Competência da mídia.

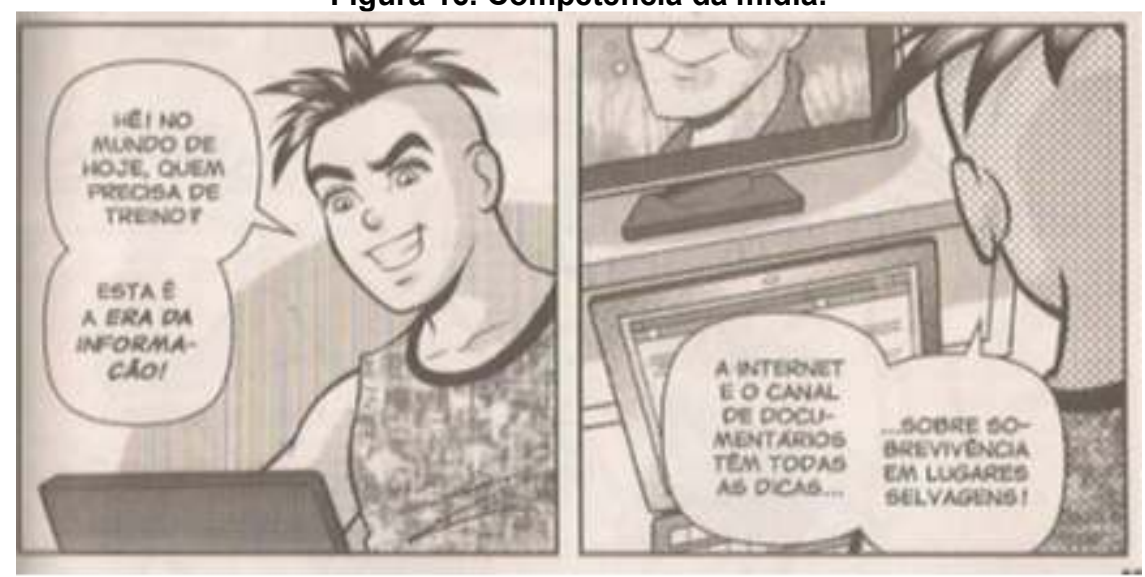

Fonte: Sousa (2013, p. 33) 
Entretanto, no decorrer da história, Cebola descobrirá que a performance não acontecerá e a sanção da narrativa vem em forma de castigo - ficar perdido no Monte, passando fome, frio, medo - onde os falsos heróis (TV, internet) são desmascarados e os verdadeiros (pais) são reconhecidos.

No terceiro programa narrativo (Figura 17), temos o ápice do conflito entre pai e filho, tema título da história em questão. Senhor Cebola descobre que o filho pretende passar uma noite no Monte do Desafio e proíbe o filho de persistir nessa ideia perigosa. Assim, Cebola tenta manipular o pai por intimidação, buscando convencê-lo a permitir a aventura. Referências à "Turma da Mônica" são utilizadas, reavivando a memória de antigos leitores, bem como de histórias anteriores de TMJ, sobre as aventuras de Cebolinha na Floresta Amazônica, no Japão e até em Marte. A questão da responsabilidade perante a vida de uma criança/adolescente é enfatizada pelos pais de Cebola, que não aceitam o argumento de que não tem idade para tal aventura.

Figura 17. Conflito de gerações

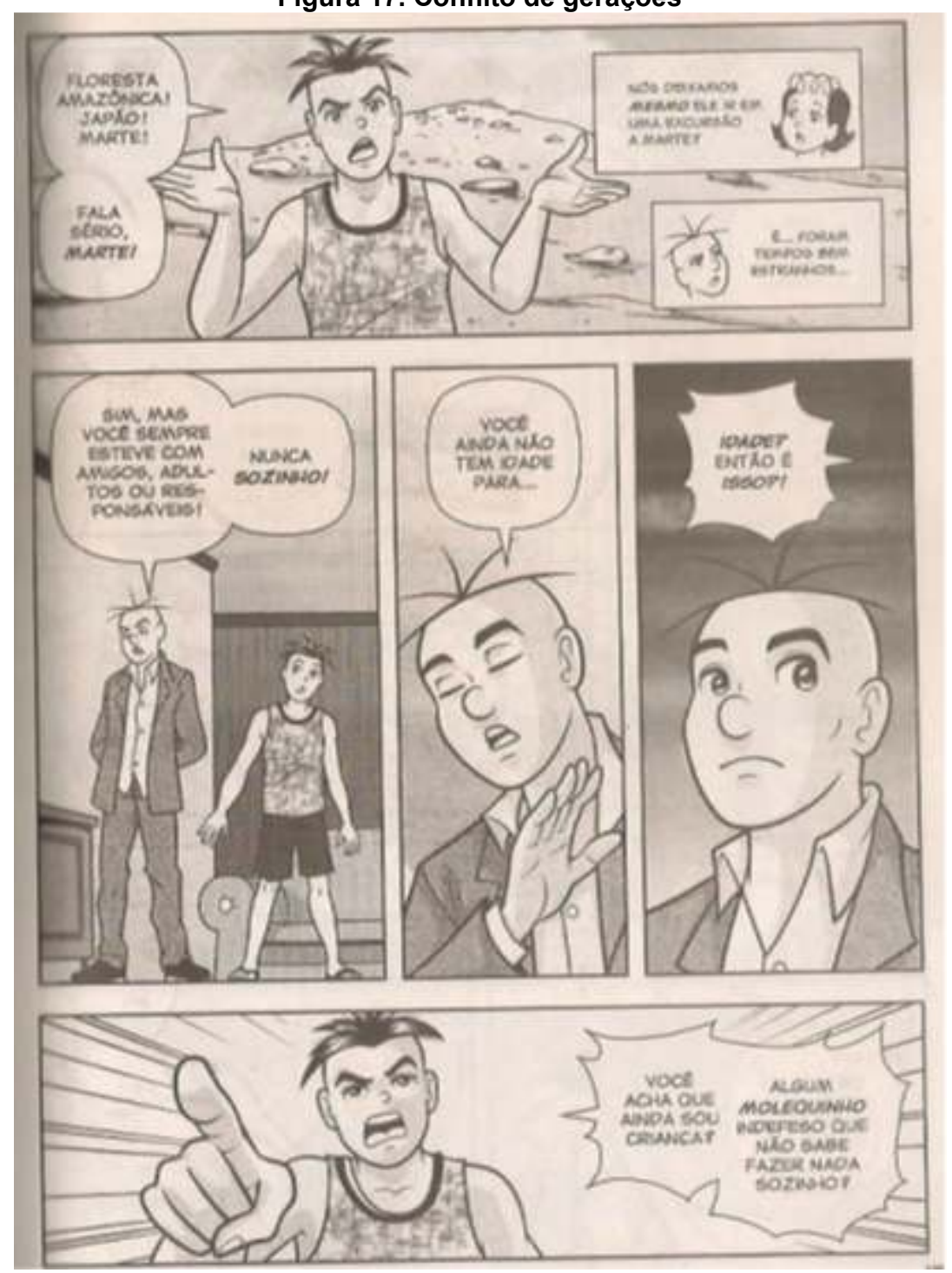

Fonte: Sousa (2013, p. 45) 
Aqui se apresenta o verdadeiro conflito de gerações, típico de uma sociedade em que as crianças e adolescentes têm, cada vez mais e precocemente, informações das mais variadas possíveis. Nesse contexto, a experiência dos pais (bem como de professores e outras referências em conhecimentos diversos), muitas vezes, é colocada em segundo plano, bem como sua confiança como fonte principal de informação. No passado, a autonomia dos pais e responsáveis, quanto ao que era melhor para seus filhos, era pouco questionada. Na sociedade atual, marcada pela Era da Informação, meios de comunicação e redes de relacionamento, tantas vezes, substituem essa fonte confiável de saber, questionando sua autoridade na relação (figura 17).

Esse conflito também se relaciona à própria fase atravessada por Cebola, a adolescência. Segundo Rocha e Pereira (2009), a adolescência é marcada pela ambiguidade e uma das primeiras ambiguidades vivenciadas por esse público é a cobrança de apresentar, ao mesmo tempo, comportamentos infantis e adultos. Nesse contexto de passagem, ora ele deve agir como criança, ora como adulto, uma expectativa complexa com que ele tem que lidar, elaborando sua identidade, "apesar de toda a dificuldade envolvida na vivência de espaços simbólicos opostos" (ROCHA; PEREIRA, 2009, p. 35). Assim, ao mesmo tempo em que Cebola deve ser adulto o bastante para assumir vários compromissos em sua vida (escolher uma profissão, etc.), ele ainda é visto como criança, por seus pais, numa situação como esta, de passar a noite sozinho, no "Monte do Desafio".

Figura 18. Conflito de gerações 2

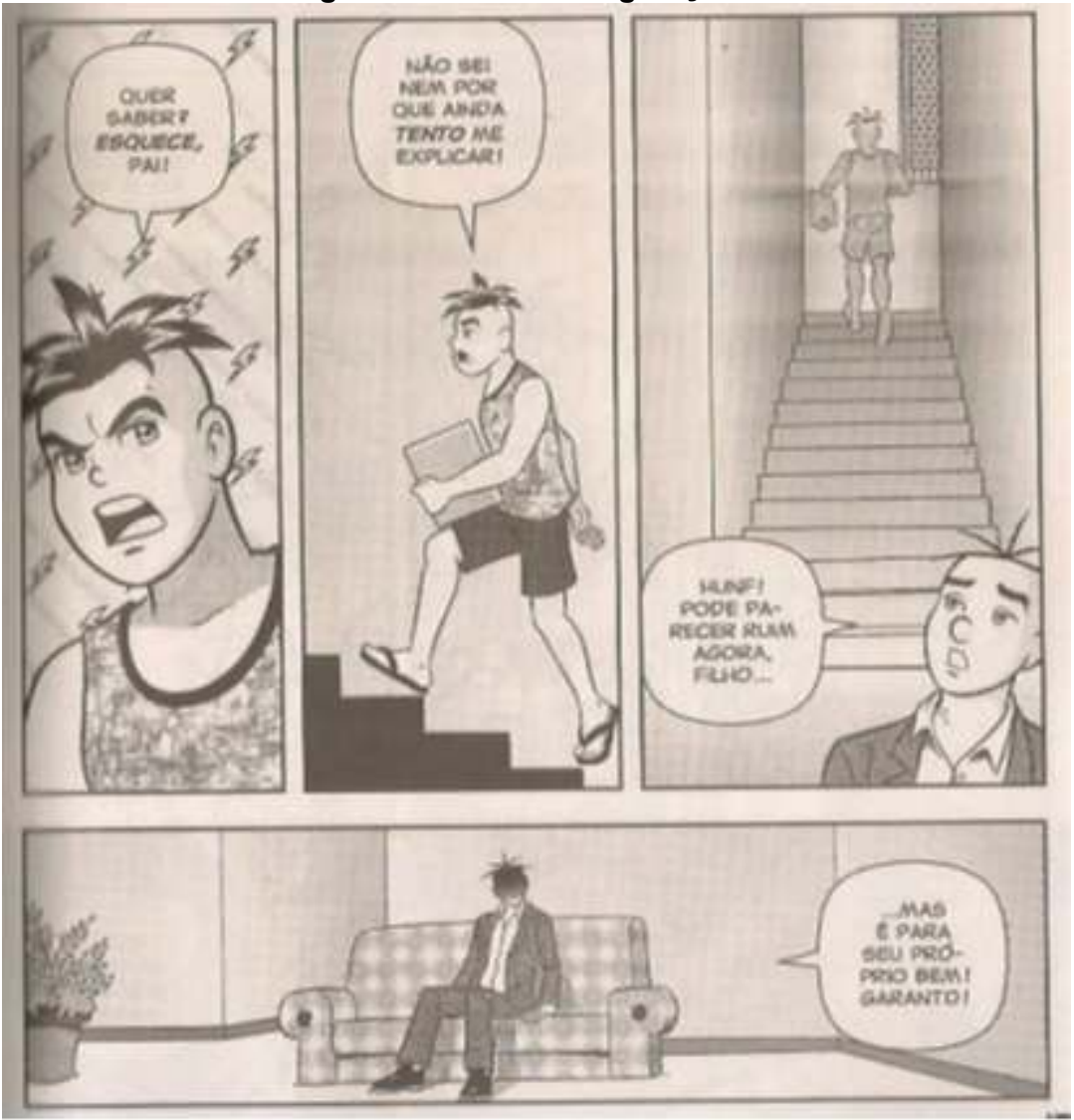

Fonte: Sousa (2013, p. 45) 
O quarto programa narrativo é o da aproximação. Senhor Cebola parte para uma nova estratégia. Em vez de bater de frente com o filho, tenta se aproximar, oferecendo seus conhecimentos como ajuda. Por meio de manipulação por sedução, o sujeito pai tenta oferecer ajuda ao sujeito filho, mostrando sua competência para a realização da performance de colocar Cebola em conjunção com a informação que precisa para enfrentar o desafio de Toni. Entretanto, Cebola não concorda com a forma de ajuda do pai (que pensa diferente dele) e considera que o mesmo só faz o atrapalhar. A diferença de pensamento entre Cebola e o pai é figurativizada nas diferentes formas de buscar informação (figuras 19 - 23).

Nesse sentido, Rocha e Pereira (2009) afirmam que o valor questionamento, presente no discurso dos adolescentes participantes de sua pesquisa, se relaciona ao desejo da experiência e à vontade de aprender como uma busca constante por novas respostas. "(...) questionar é uma forma de aprendizado e compreensão de valores e instituições - escola, religião, política, família - estabelecidas em um mundo que os adolescentes não construíram e que thes é apresentado como verdadeiro" (ROCHA; PEREIRA, 2009, p. 43).

Figura 19. Ajuda ou atrapalha?

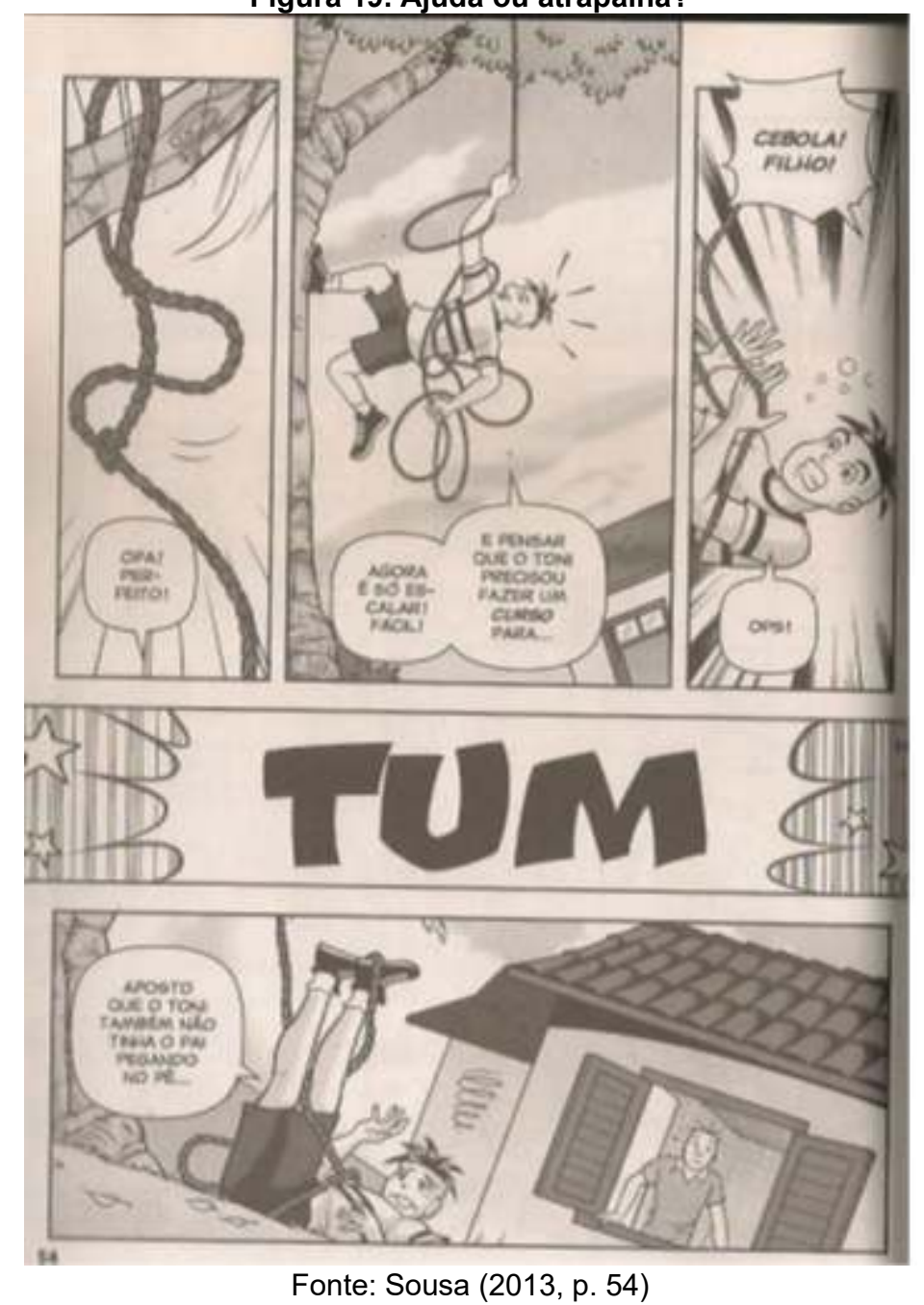

Fonte: Sousa (2013, p. 54) 
Figura 20. Fonte de informação Cebola

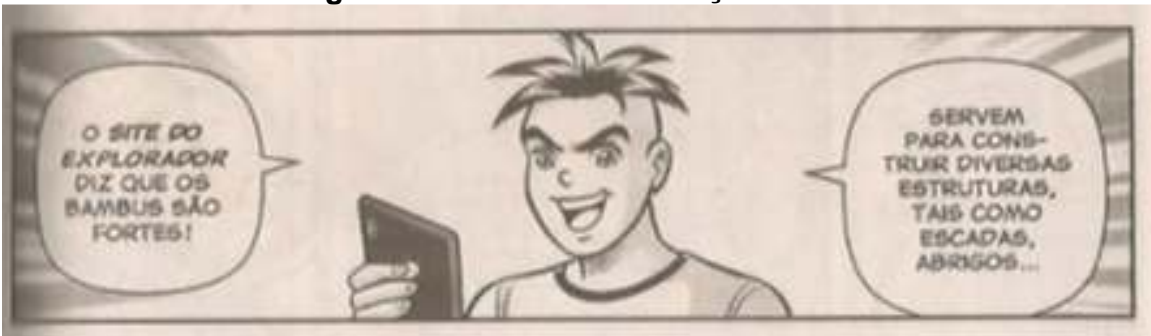

Fonte: Sousa (2013, p. 55)

Figura 21. Ajuda ou atrapalha 2?

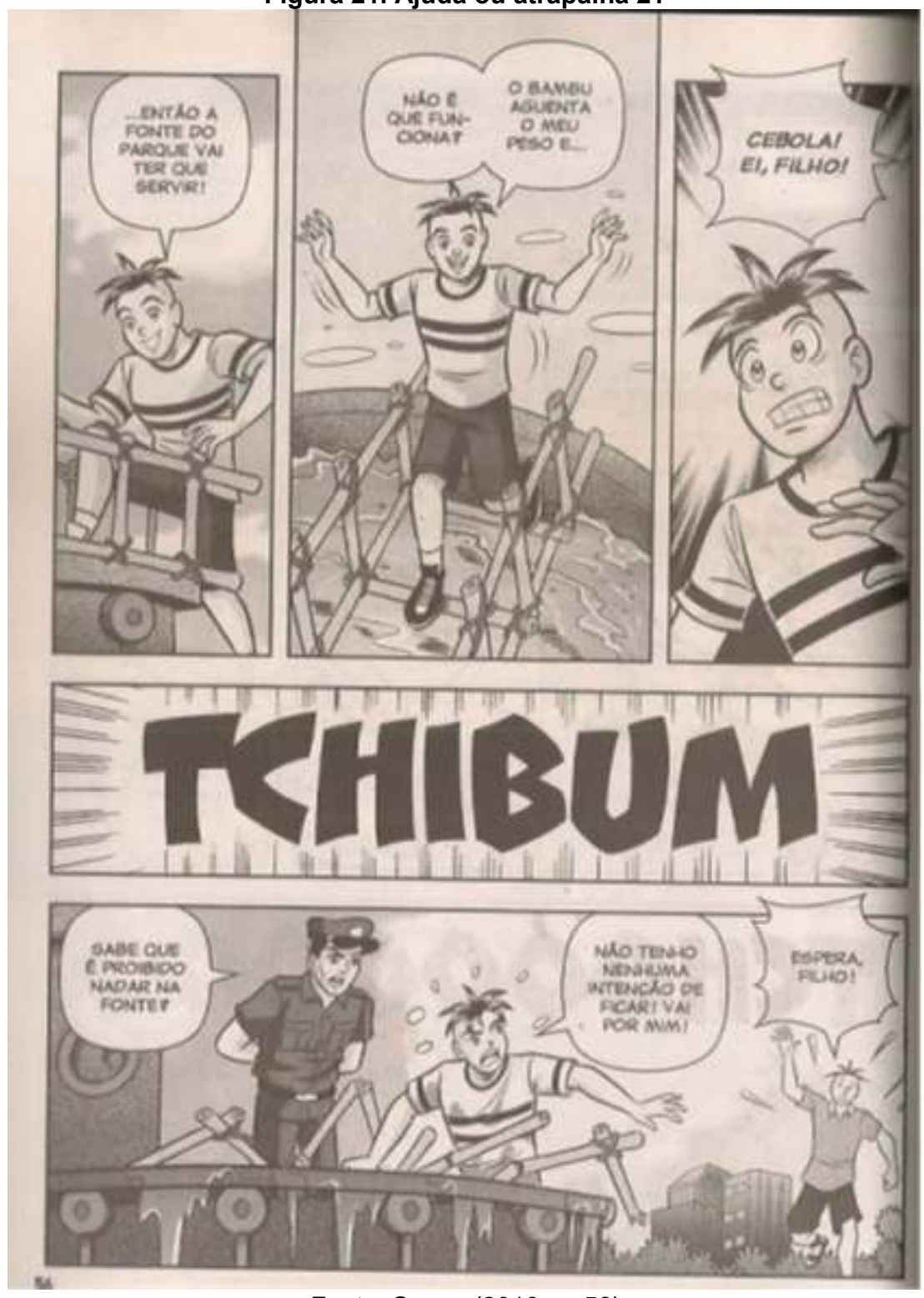

Fonte: Sousa (2013, p. 56) 
Figura 22. Fonte de informação Cebola 2

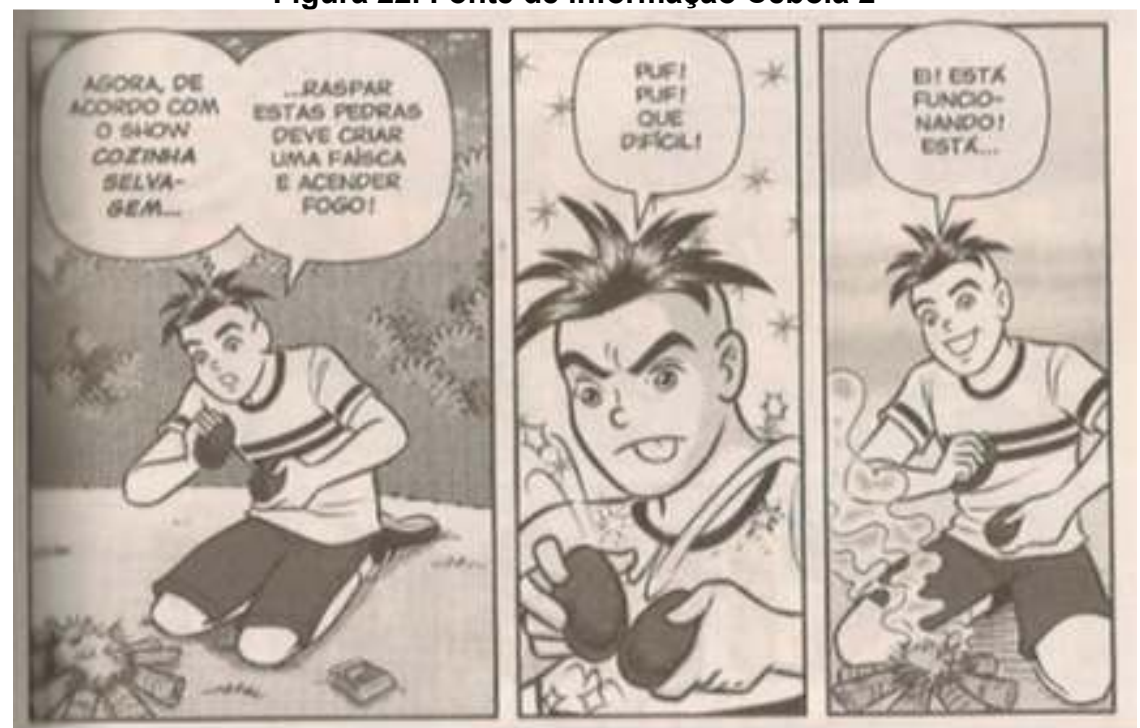

Fonte: Sousa (2013, p. 57)

Figura 23. Ajuda ou atrapalha 3?

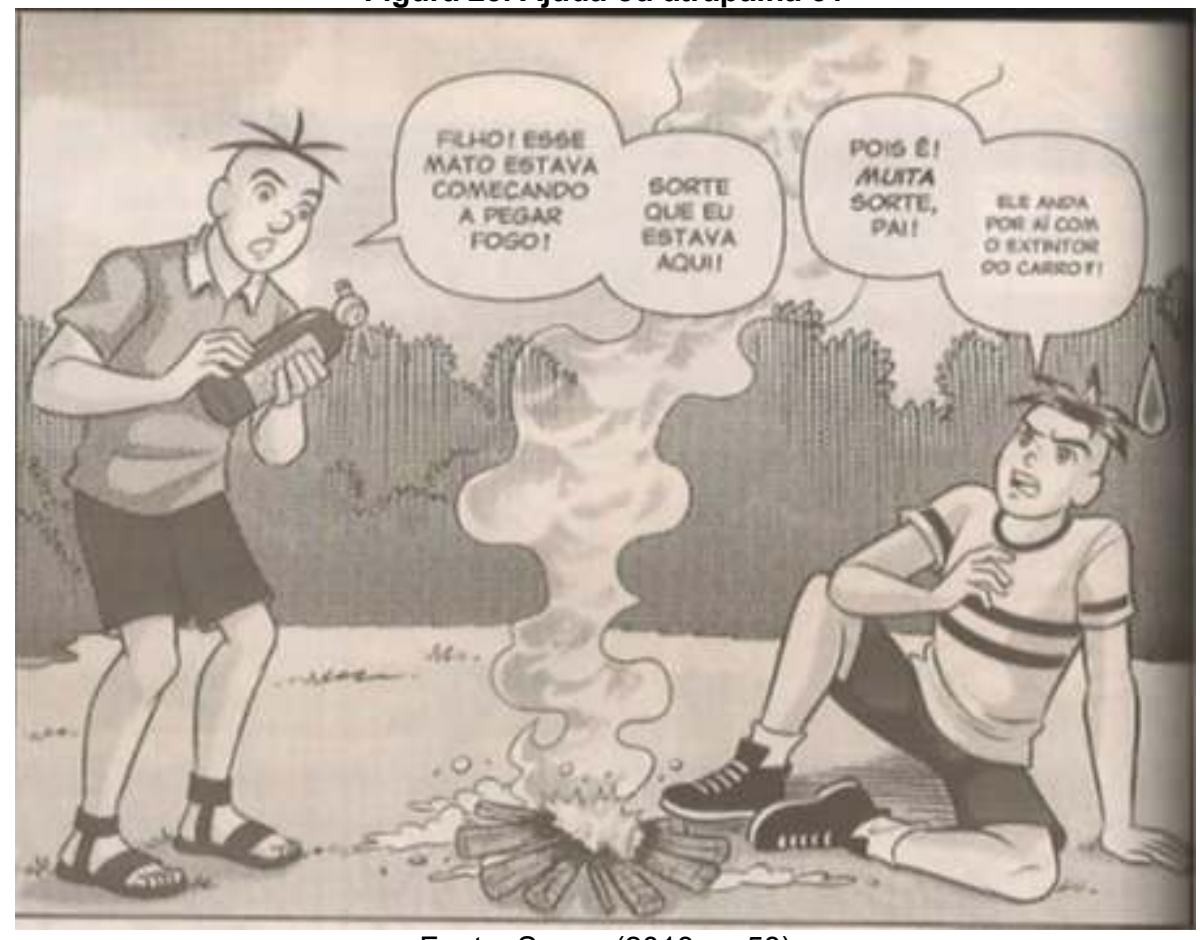

Fonte: Sousa (2013, p. 58) 
Figura 24. Fonte de informação Senhor Cebola

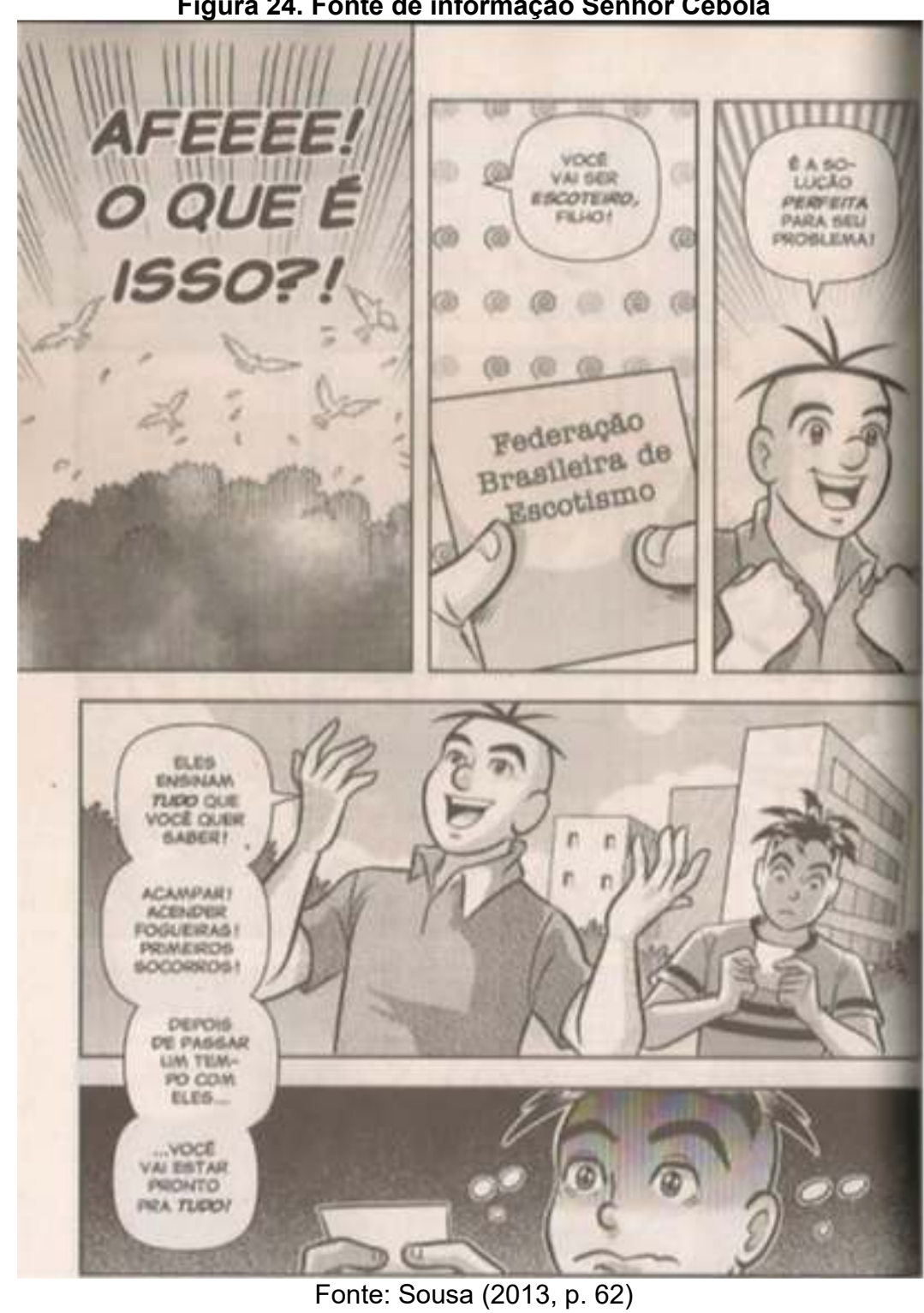

Nesse ponto da narrativa (figura 24), fica clara a diferença de concepções de mundo entre pai e filho. Senhor Cebola sugere que o filho entre para os escoteiros, porém Cebola considera esta uma instituição brega, velha, ultrapassada, conflito que afasta ainda mais pai e filho. Assim, o pai é visto pelo filho como uma pessoa chata, limitada, ultrapassada, no momento em que este o compara com os escoteiros (papel que fez parte da infância do Senhor Cebola). 
Fernandes (2008) fala sobre a dificuldade de comunicação entre gerações, uma vez que, segundo ela, as narrativas de hoje são quebradas, muito devido à relação dos jovens com a mídia, uma das grandes responsáveis por esse começar de novo constante, que faz com que os que chegam depois não consigam acompanhar as novidades e, assim, nem sempre conseguem trocar. A experiência hoje talvez seja um convite a viver algo junto para depois poder comentar sobre a experiência que ambos viveram.

(...) com a presença da mídia, esse olhar muda constantemente e o olhar de ontem já não é mais fonte de experiência para aquele que olha hoje. Assim, a vivência do mais experiente (entendido como aquele que é mais velho) não tem o mesmo valor que tinha tradicionalmente. A não ser que o mais experiente seja entendido não como o que viveu mais tempo, mas como o que olhou mais (...) (FERNANDES, 2008, p. 189).

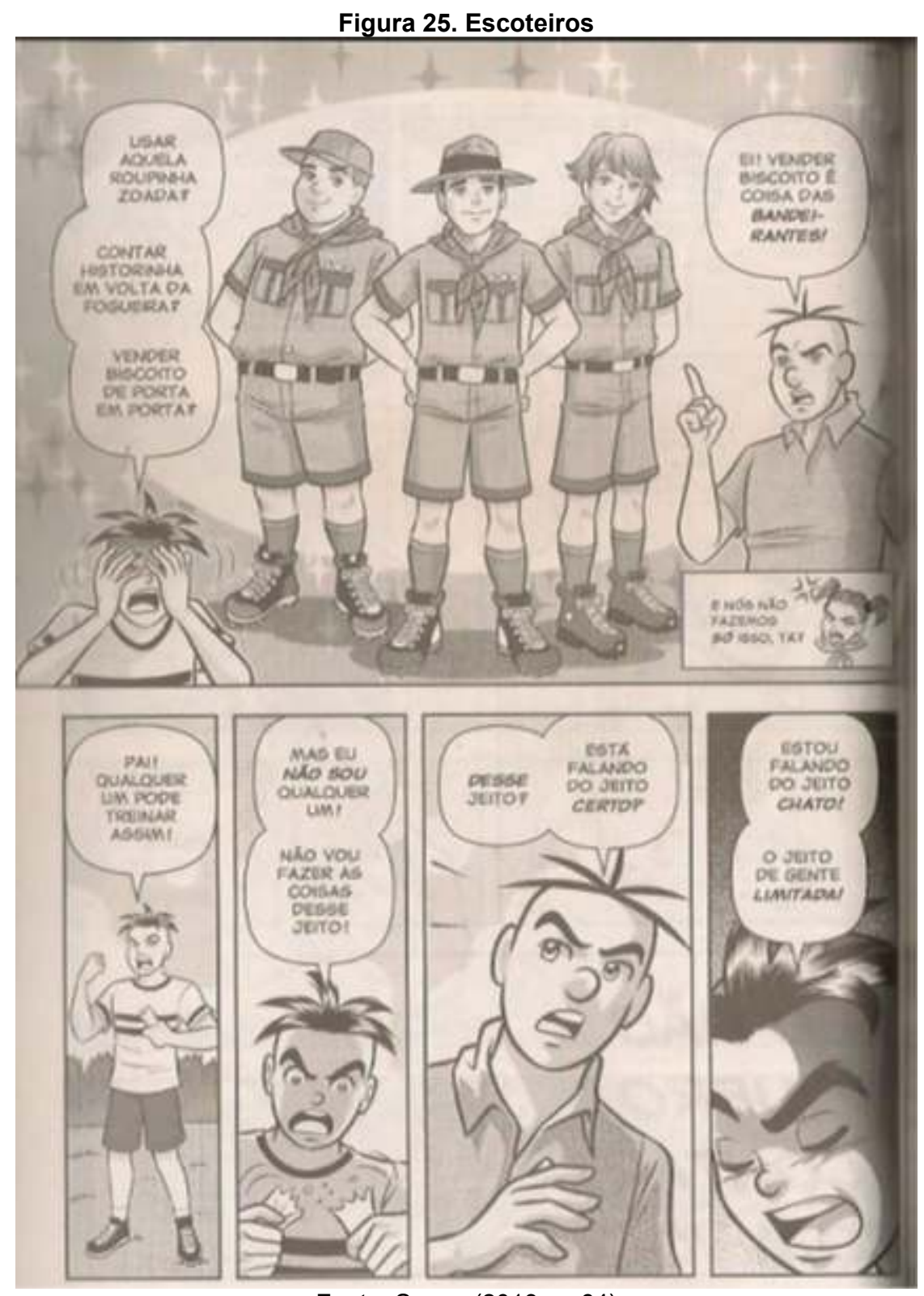

Fonte: Sousa (2013, p. 64) 
Figura 26. Eu não quero contar com você

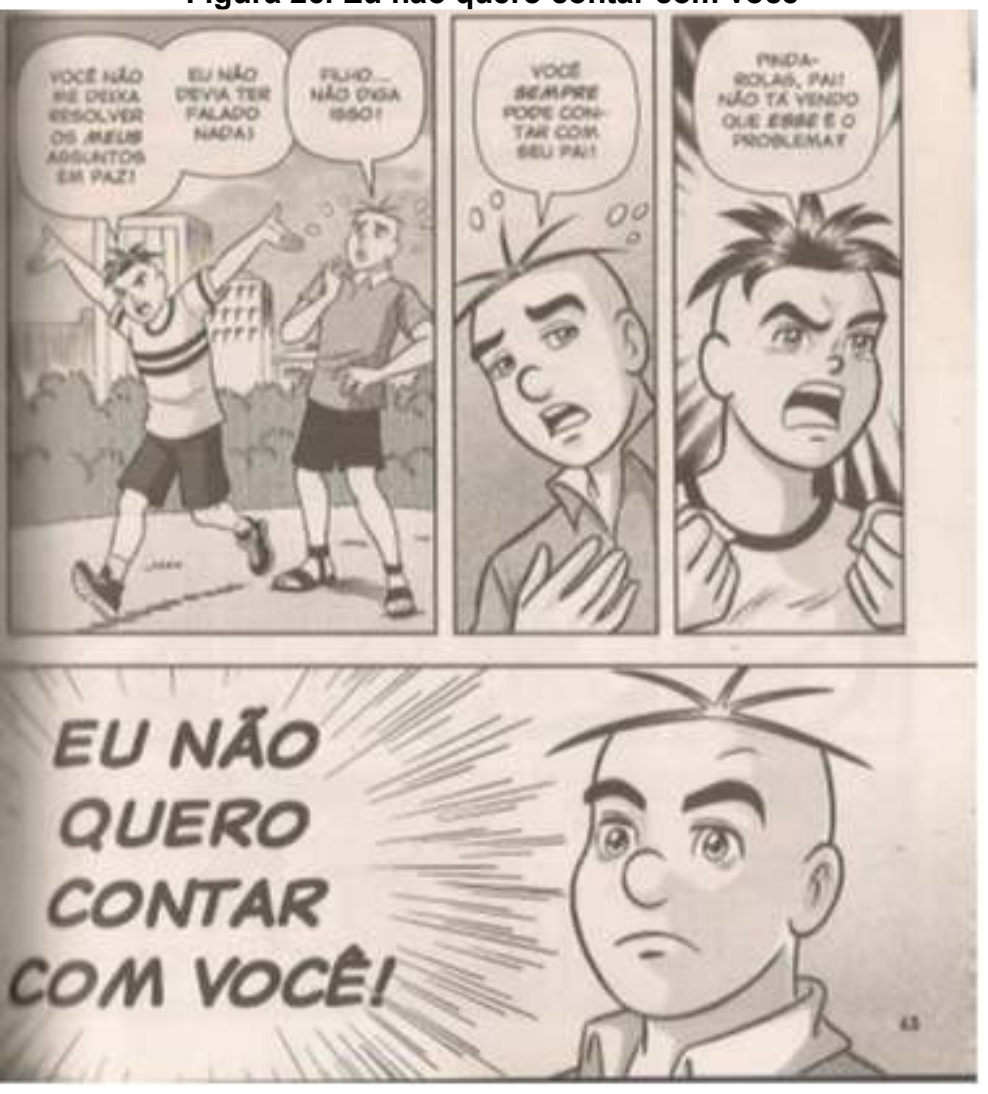

Fonte: Sousa (2013, p. 65)

Diante da situação desencadeada e após ser desrespeitado, Senhor Cebola, o sujeito do fazer, mostra sua competência como pai, por meio da autoridade perante o filho, e realiza a performance de deixar Cebola de castigo, colocando-o em disjunção com a informação, a partir do momento em que proíbe o uso de celular e internet, por uma semana. Essa situação remete, novamente, à sociedade de consumo contemporânea, uma vez que os "castigos" da Era da Informação são outros, distintos de tempos anteriores (não poder brincar na rua, palmadas, ficar sem comer o que gosta, etc.). Assim, Cebola (figura 27) pensa que o pai vai Ihe bater (primeiro, expressão assustada, olhos arregalados, boca aberta, mãos erguidas; depois, expectativa para receber a punição física, olhos fechados apertados, suor na testa), mas, para sua surpresa, o castigo é "pior" (na visão das crianças e adolescentes pós-modernos), porque representa a privação aos gadgets eletrônicos e o acesso à rede (internet). No contexto da história, essa privação também consiste em um obstáculo ao desafio de Cebola e Toni, uma vez que o personagem principal não tem mais acesso às fontes de informações (que ele julga confiáveis) para se preparar para a aventura. 
Figura 27. Castigos da Era da Informação

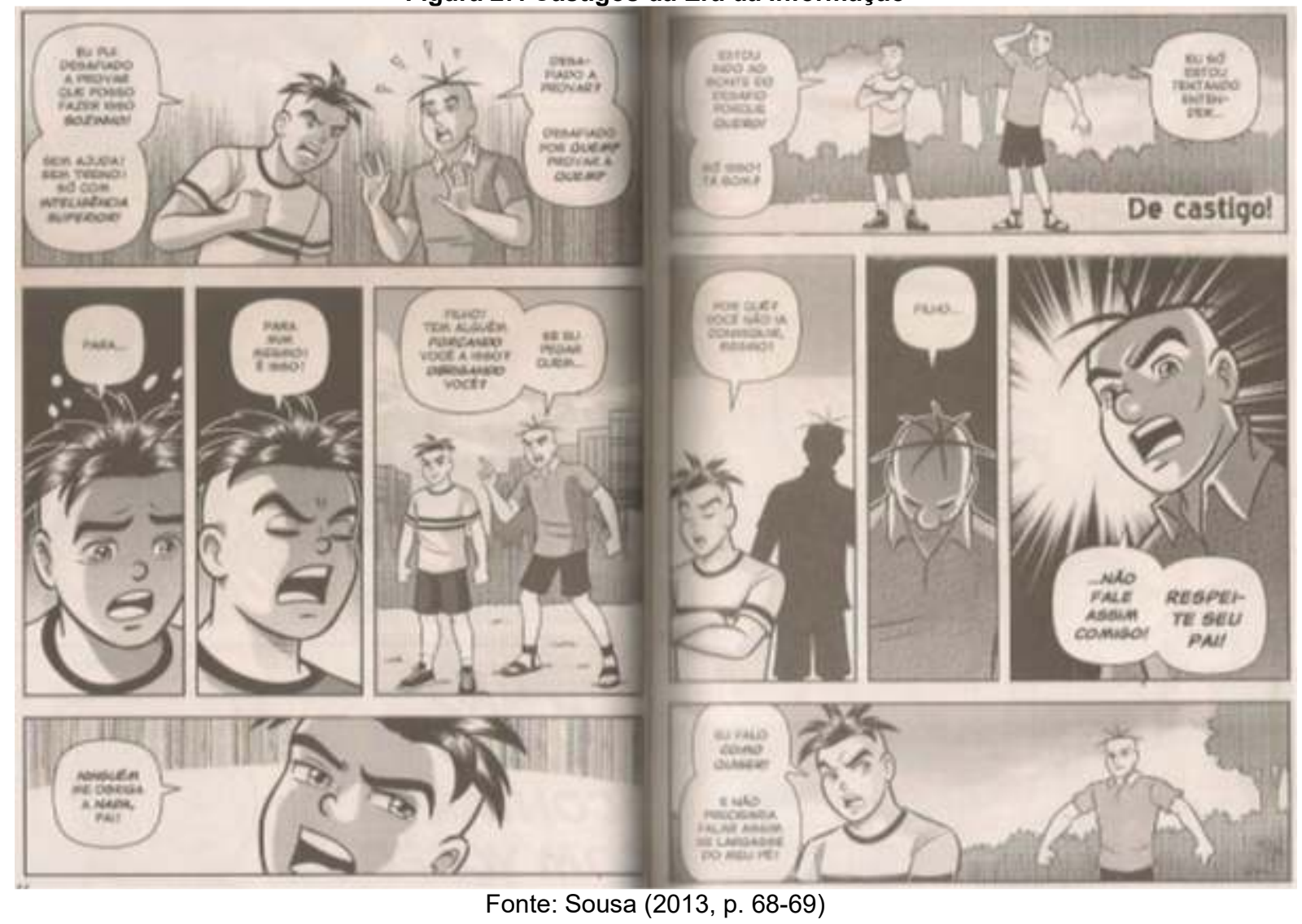

Figura 28. Perdido na mata
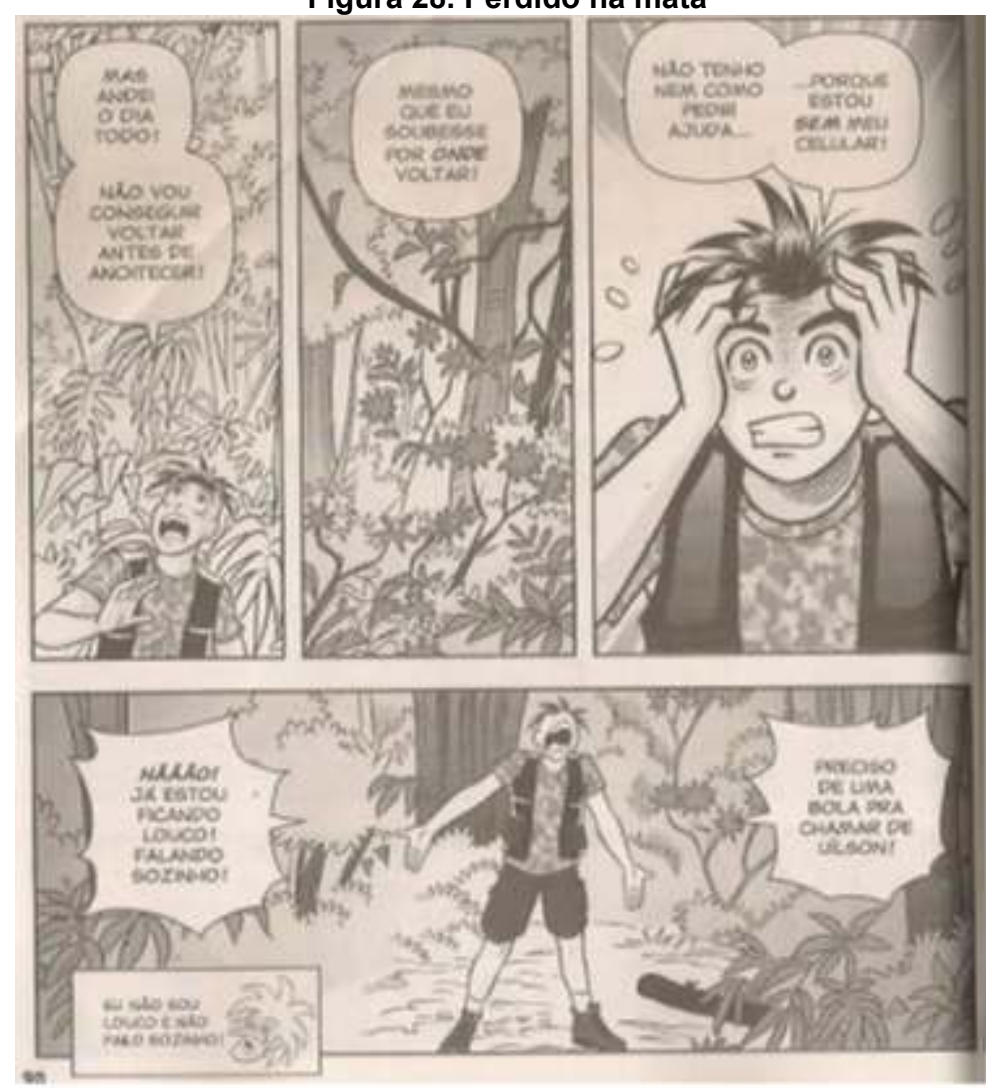

Fonte: Sousa (2013, p. 90) 
Essa dependência de aparelhos eletrônicos e de ter acesso ilimitado e ininterrupto à comunicação e à informação também são reiterados, quando Cebola se vê sozinho no meio da mata, perdido, com fome, frio, desesperado e o que ele mais deseja, nesse momento, é seu celular. Ainda, mais uma intertextualidade com o cinema aparece, nessa parte da história (figura 28), com Cebola fazendo referência ao filme "Náufrago" (EUA: Universal Pictures, 2000), dirigido por Robert Zemeckis, com Tom Hanks, em que o personagem, sozinho em uma ilha deserta, cria um amigo, a partir de uma bola de vôlei da marca Wilson (que acaba sendo o nome desse amigo imaginário).

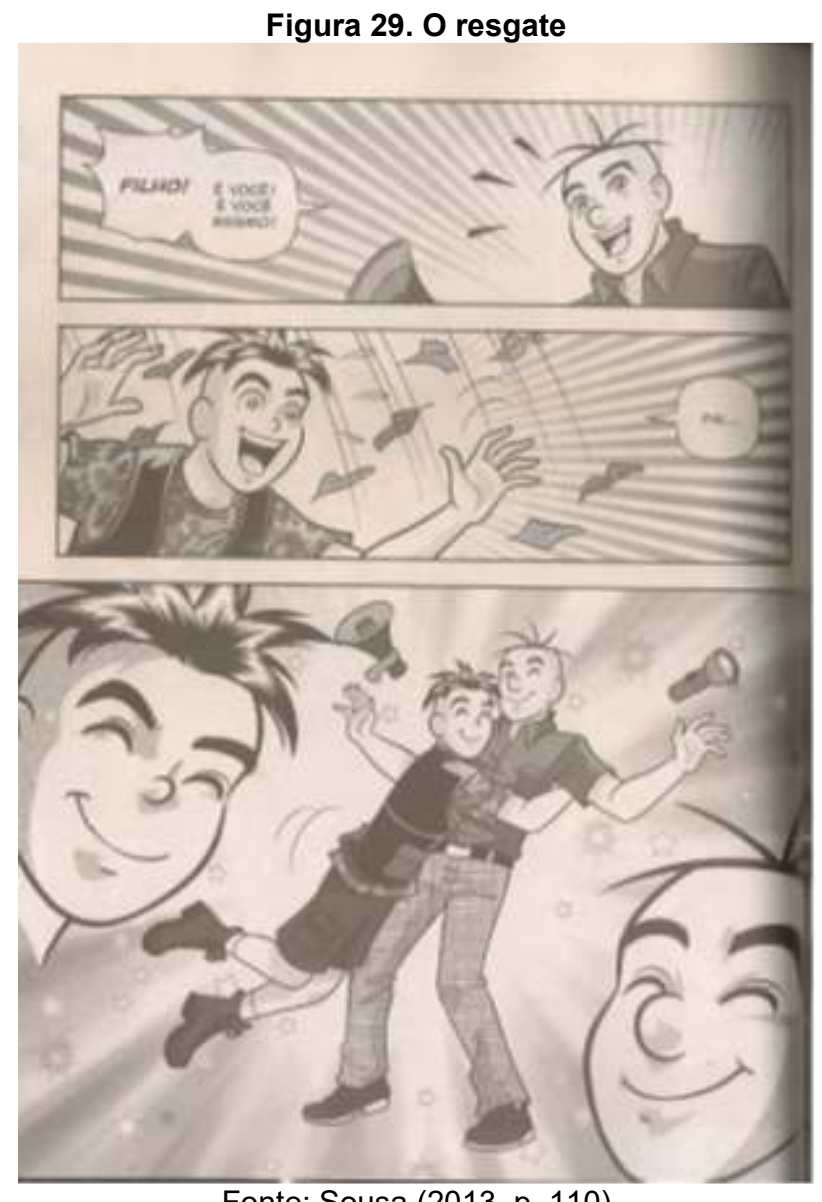

Fonte: Sousa (2013, p. 110)

Figura 30. Pai-herói

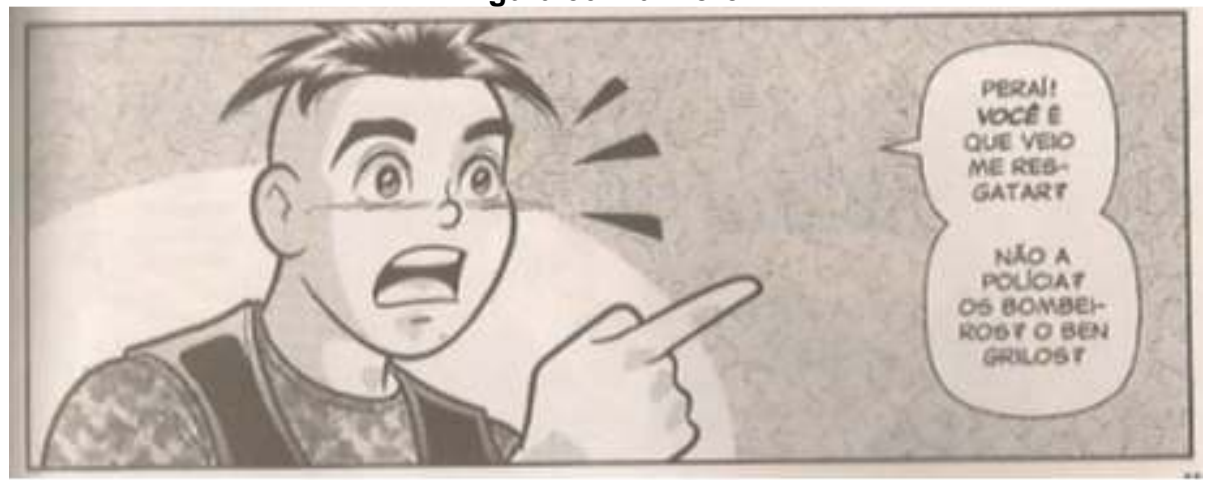

Fonte: Sousa (2013, p. 111) 
O último programa narrativo trata do reconhecimento da importância do pai. Temos o sujeito do fazer - Sr. Cebola - que tem a competência para realizar a performance, que é encontrar o seu filho, no Monte do Desafio, antes mesmo da polícia e dos bombeiros (Figuras 29 e 30). É o reconhecimento do pai pelo filho, que resgata a confiança de Cebola na família (conjunção com os valores familiares), em detrimento da confiança "cega" nas informações midiáticas. Assim, Senhor Cebola que, em determinado momento, era visto por seu filho como o anti-sujeito da trama, impedindo sua ação de ir ao Monte do Desafio sozinho, acaba se transformando no pai-herói. Nesse enunciado, temos uma situação de liquidação de privação, em dois sentidos: Cebola estava em disjunção com a resolução de um problema (sobreviver ao Monte do Desafio), perdido, com frio, fome e medo; ainda, Cebola também estava em disjunção com a confiança no pai, na família. No momento em que é encontrado pelo Senhor Cebola, ele entra em conjunção com a saída do Monte, por meio da confiança no pai.

Figura 31. A competência do pai 1

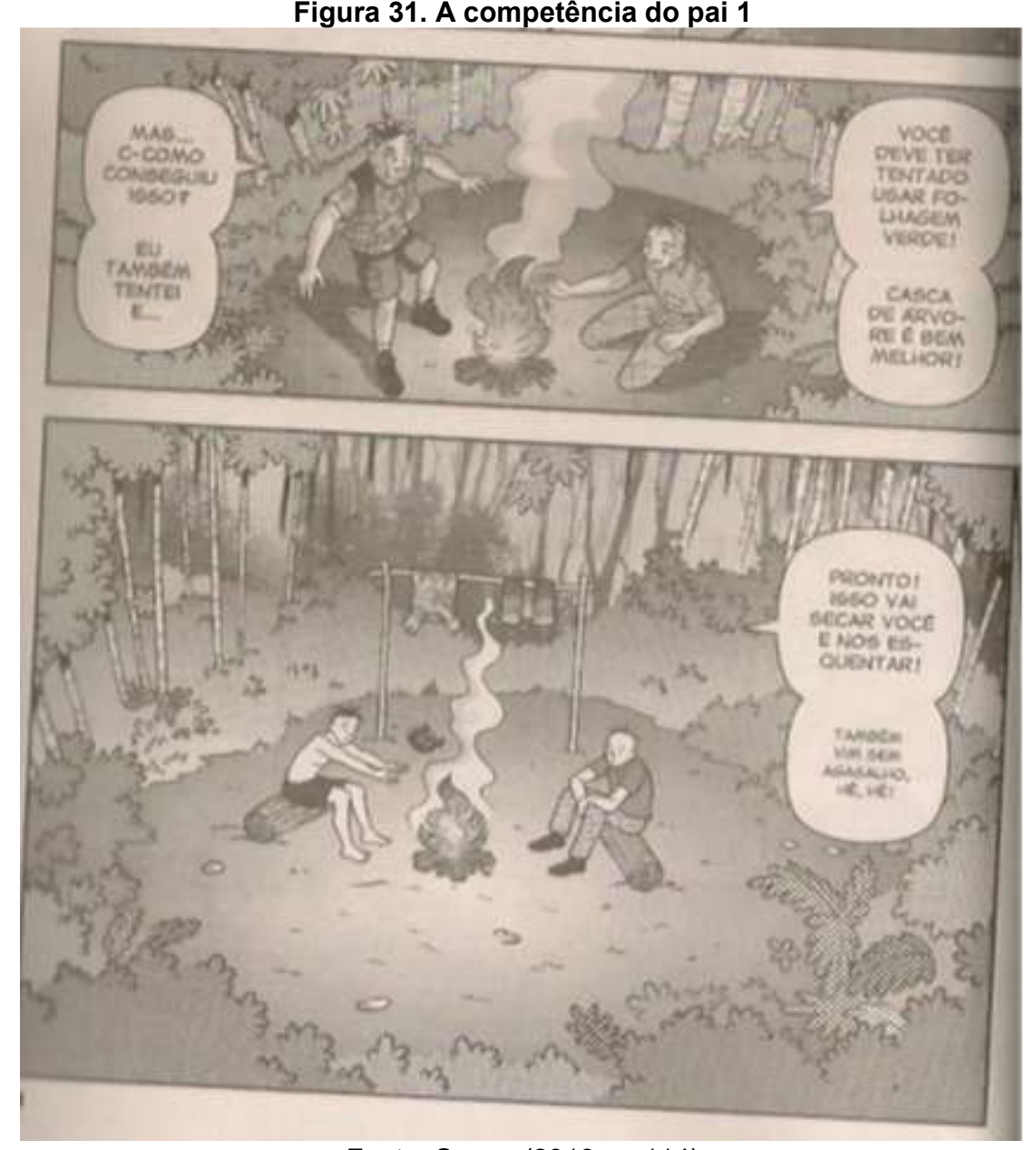

Fonte: Sousa (2013, p. 114)

Por meio de manipulação por sedução, o pai vai mostrando ao filho todo o seu conhecimento sobre sobrevivência na selva, bem como as fontes responsáveis por essas informações. Assim, ele prova sua competência em realizar a performance de tirá-los dali. 
Figura 32. A competência do pai 2

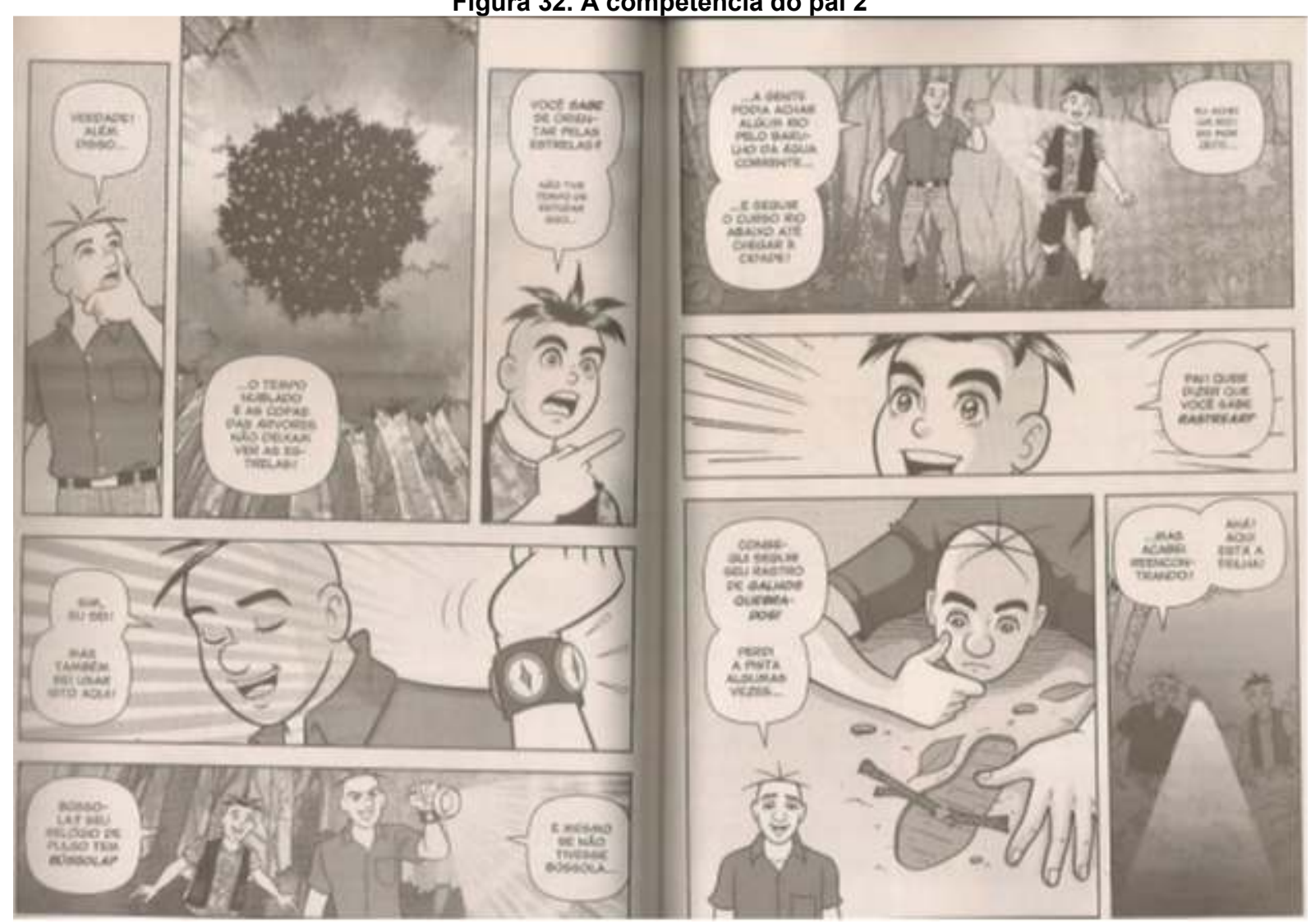

Fonte: Sousa (2013, p. 116-117)

Na pesquisa com os adolescentes de Rocha e Pereira (2009), ficou confirmado o desejo de liberdade, porém eles também anseiam por algum controle, identificando certa positividade sobre a autoridade da escola e da família, no sentido de oferecer liderança, orientações, estabelecimento de limites e balizamento de experiências, para o bem de seu futuro pessoal e profissional. Assim, eles entendem o excesso de liberdade como uma espécie de abandono. No momento em que Cebola percebe a importância da preocupação e controle de seu pai, esse sentimento é confirmado.

Dentro desse contexto, Salgado (2008) identificou, em sua pesquisa sobre desenhos animados infantis, que esses ora acentuam o abismo existente entre as gerações, naturalizando práticas sociais definidoras de novos tipos de hierarquias, como exemplo, a questão do poder infantil em detrimento da autoridade adulta, ora convidam crianças e adultos a dialogarem sobre suas relações, papéis e lugares sociais, na cultura contemporânea. 
Figura 33. A admiração

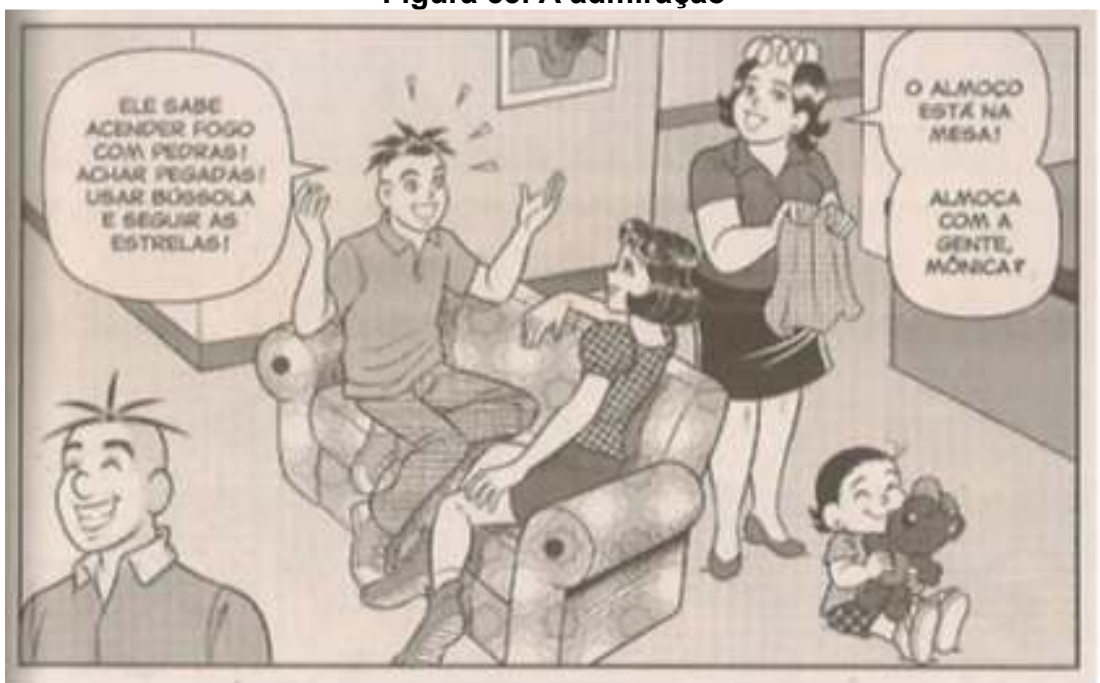

Fonte: Sousa (2013, p. 121)

Figura 34. A sanção

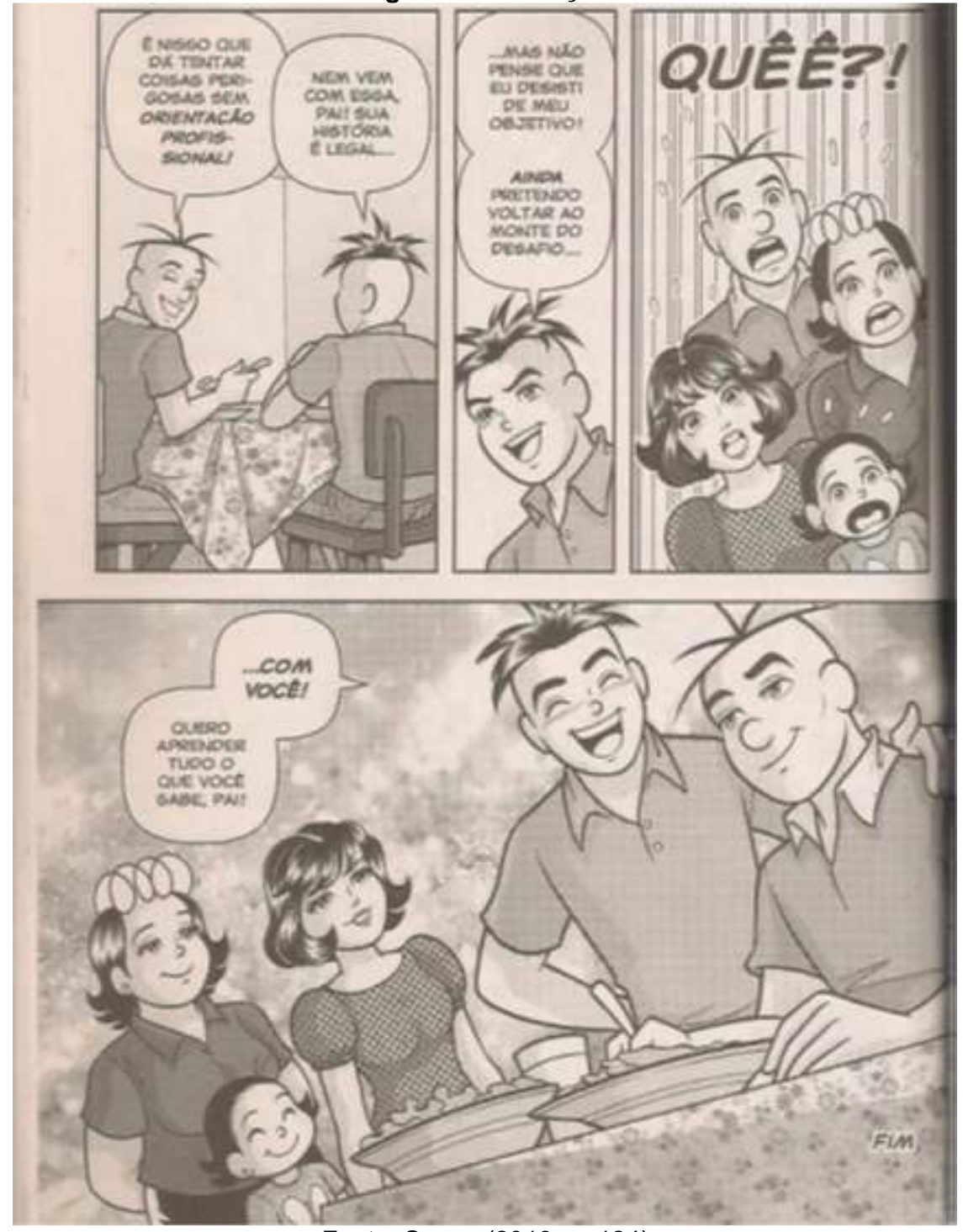

Fonte: Sousa (2013, p. 124) 
A sanção da história se dá com a volta de pai e filho para casa, sãos e salvos. Nesse contexto, há o reconhecimento do sujeito que operou a transformação, no caso, Senhor Cebola, que recebe como prêmio a admiração e a confiança do filho, bem como a promessa de uma amizade ainda maior entre ambos - Cebola quer voltar ao "Monte do Desafio" acompanhado do pai e aprender tudo o que ele sabe (figura 33). Nessa fase, os castigos também são distribuídos e, nesse caso, Cebola vai continuar sem celular por mais dois meses. No nível mais profundo do percurso gerativo de sentido, o fundamental, temos os valores que permeiam a história em questão: /antigo/ versus /novo/, ou seja, /tradição/ versus /modernidade/, isso porque Cebola desconfia do que é antigo, acha ultrapassado e o rejeita, aceitando apenas o que é novo, moderno, contemporâneo.

\section{CONSIDERAÇÕES FINAIS}

Observamos que o consumo está muito presente, ao longo das tramas de TMJ, tendo aparecido como temática principal, em mais de 60\% das revistas publicadas, nos anos de 2012, 2013 e 2014. Também, ele é apropriado pela revista como modo de reprodução social vigente, ou seja, uma vez que vivemos em uma "sociedade de consumo" e a revista busca reiterar temáticas que fazem parte do dia-a-dia de seu público leitor, o consumo acaba aparecendo com frequência, no discurso da revista, como forma de contextualizar um tempo, um local, um modo de vida, próprio dessa geração.

Dentro do contexto da análise das revistas categorizadas dentro da temática de consumo moralista, dentre elas - Conflito de Gerações, objeto de análise deste artigo - foi possível estabelecer uma relação entre a categoria de consumo moralista e a problemática do consumo de informações via web, uma reiteração da isotopia temática da crítica ao uso irresponsável da tecnologia (tecnologia em detrimento à confiança nos pais; tecnologia divulgando informações caluniosas; bem como outros casos, não analisados aqui, como o uso da tecnologia para arrumar uma namorada virtual - TMJ 59, "Encontro Marcado").

Assim, ao longo dos três anos analisados, na tese a partir de que este artigo foi gerado - 2012, 2013 e 2014, o consumo moralista aparece, em TMJ, promovendo um alerta ao consumo desordenado de informações na internet, reiterando uma característica marcante do público infantojuvenil da revista, uma vez que seu discurso figurativiza essa relação jovens $x$ tecnologia, o tempo todo. Ainda, a categoria de consumo moralista tem foco no público masculino, colocando os meninos como personagens principais das tramas ou situações apresentadas (Cebola, em TMJ 58 e 59; Fabinho, em TMJ 57).

Assim, as revistas que tratam dessa temática trazem uma forte preocupação do enunciador em relação ao uso irresponsável da tecnologia. Também de caráter sexista, no momento em que coloca os meninos como os maiores usuários e manipuladores de gadgets eletrônicos, o discurso de TMJ tenta alertar o enunciatário para os perigos do ambiente virtual e da confiança única, nas informações nele divulgadas. É uma preocupação válida e importante, em se tratando da geração atual.

Em relação às estratégias enunciativas utilizadas pela revista para atrair o público infantojuvenil, há uma adoção de papéis identitários diversos que buscam uma aproximação, a partir do reconhecimento do leitor. Suas roupas, cabelos, acessórios, linguagem, bem como os locais por onde circulam (escola, praia, shopping etc) são construídos, intencionalmente, como estratégias enunciativas que geram imediata familiaridade com seu público. É o caso dos gadgets eletrônicos, como smartphones, tablets, notebooks, muito presentes nas histórias de TMJ e considerados, por estudiosos como Rocha e Pereira (2009), símbolos 
dessa geração de que faz parte o público leitor da revista. Essa estratégia gera um sentimento de pertencimento, em seus leitores provocado por um "querer ser" os personagens de TMJ e, ao mesmo tempo, "um querer ter" aquilo que eles têm.

Como afirma Orofino (2014, p. 67-68), precisamos estar atentos a todas essas mudanças desencadeadas pela emergência da cultura digital e, enquanto adultos, prestar atenção e cuidar das nossas crianças. Alertas à condição de sujeito da criança e que se trata de um sujeito em formação, todos nós adultos precisamos compartilhar essa responsabilidade. "As mídias estão quase onipresentes. A sorte das crianças é que a vida social é muito mais do que a mídia. Mas não podemos negar o peso que a mídia ocupa na socialização das crianças dos nossos novos tempos".

\section{REFERÊNCIAS}

BARBOSA, Lívia. Sociedade de consumo. Rio de Janeiro: Jorge Zahar Ed., 2004.

BARBOSA, Lívia; CAMPBELL, Colin. Org. Cultura, consumo e identidade. Rio de Janeiro: Editora FGV, 2006.

BARROS, Diana Luz Pessoa de. Teoria Semiótica do Texto. São Paulo: Ática, 2002.

CANCLINI, Néstor García. Consumidores e cidadãos: conflitos multiculturais da globalização. 4 ed. Rio de Janeiro: UFRJ, 1999.

CEBOLINHA n² 211. Wiki Turma da Mônica. Janeiro 2004. Disponível em < http://ptbr.monica.wikia.com/wiki/Cebolinha_n\%C2\%BA_211> Acesso em 06 maio 2014.

FERNANDES, Adriana Hoffman. Mangá e produção de sentidos: reflexões sobre narrativa e contemporaneidade. In: OSWALD, Maria Luiza M. Bastos; PEREIRA, Rita Marisa Ribes. (org) Infância e Juventude: narrativas contemporâneas. Petrópolis: DP et al; Rio de Janeiro: Faperj, 2008.

FIORIN, José Luiz. Elementos de análise do discurso. 15. ed. São Paulo: Contexto, 2011.

MCNEAL; James U. On becoming a consumer: development of consumer behavior patterns in childhood. USA: Elsevier, 2007.

MOREIRA; Alberto da Silva. Cultura Midiática e Educação Infantil. Educ. Soc., Campinas, vol. 24, n. 85, p. 1203-1235, dezembro 2003. Disponível em < http://www.scielo.br/pdf/es/v24n85 /a06v2485> Acesso em 09 dezembro 2014.

OROFINO, Maria Isabel Rodrigues. Crianças em contextos: novos aportes para o debate sobre infâncias, comunicação e culturas do consumo. In: ROCHA, Rose de Melo; OROFINO, Maria Isabel Rodrigues. (org) Comunicação, Consumo e Ação Reflexiva: caminhos para a educação do futuro. Porto Alegre: Sulina, 2014.

OSWALD, Maria Luiza M. Bastos; PEREIRA, Rita Marisa Ribes. Apresentação. In: OSWALD, Maria Luiza M. Bastos; PEREIRA, Rita Marisa Ribes. (org) Infância e Juventude: narrativas contemporâneas. Petrópolis: DP et Alii; Rio de Janeiro: Faperj, 2008.

PESQUISA Kids Experts. Cartoon Network. Disponível em http://www.alana.org.br/CriancaConsumo/Biblioteca.aspx?v=6\&pes=17 Acesso em 29 abril 2014.

ROCHA, Everardo. Culpa e prazer: imagens do consumo na cultura de massa. Comunicação, mídia e consumo. São Paulo. Vol. 2 N. 3 p. 123-138 Março 2005.

ROCHA, Everardo; PEREIRA, Cláudia. Juventude e consumo: um estudo sobre a comunicação na cultura contemporânea. Rio de Janeiro: Mauad X, 2009.

SALGADO, Raquel Gonçalves. Entre a ficção e a realidade: as facetas do poder infantil na cultura contemporânea. In: OSWALD, Maria Luiza M. Bastos; PEREIRA, Rita Marisa Ribes. (org) Infância e Juventude: narrativas contemporâneas. Petrópolis: DP et Alii; Rio de Janeiro: Faperj, 2008.

SANTANA, Erivelton Nonato de. Gibi, o aparelho ideológico quadrinizado: considerações sobre a diversidade discursiva e o caráter instrutivo-educativo nas histórias da Turma da Mônica. 2007. 196 f. Tese (doutorado) - Programa de PósGraduação em Letras e Lingüística, Instituto de Letras, Universidade Federal da Bahia, Salvador, 2007.

SOUSA, Maurício de. Surge uma estrela. Revista Turma da Mônica Jovem. n. 19. São Paulo: Panini Comics, 2010. Tesouro Verde - Parte 1. Revista Turma da Mônica Jovem. n. 43. São Paulo: Panini Comics, 2012. Sombras do Passado - Parte Final. Revista Turma da Mônica Jovem. n. 52. São Paulo: Panini Comics, 2012. Conflito de Gerações. Revista Turma da Mônica Jovem. n. 58. São Paulo: Panini Comics, 2013. 
Encontro Marcado. Revista Turma da Mônica Jovem. n. 59. São Paulo: Panini Comics, 2013.

. A nova Mônica. Revista Turma da Mônica Jovem. n. 61. São Paulo: Panini Comics, 2013.

Campeões da Justiça. Revista Turma da Mônica Jovem. n. 62. São Paulo: Panini Comics, 2013.

2013.

. A brigada dos ossos cruzados parte 1. Revista Turma da Mônica Jovem. n. 65. São Paulo: Panini Comics,

. A decisão. Revista Turma da Mônica Jovem. n. 68. São Paulo: Panini Comics, 2014.

TEIXEIRA, Lucia. Para uma metodologia de análise de textos verbovisuais. In: OLIVEIRA, Ana Claudia de. TEIXEIRA, Lucia. Org. Linguagens na Comunicação: desenvolvimentos de semiótica sincrética. São Paulo: Estação das Letras e Cores, 2009.

VELOSO, Andres Rodriguez; HILDEBRAND, Diogo; CAMPOMAR, Marcos Cortez. Marketing e o mercado infantil. São Paulo: Cencage Learning, 2012.

YOUNG, Brian. The growing consumer. Young Consumers. Quadrimestre 4, p. 22-29, 2004.

ZUKIN, Sharon; MAGUIRE, Jennifer Smith. Consumers and consumption. Annual Review of Sociology. V.30, p.173-97, 2004. 